OPEN ACCESS

Edited by:

Ivan Hiltpold,

University of Delaware, USA

Reviewed by:

Lei Zhang,

Washington State University, USA

Ronald Albert Prestidge

AgResearch Pty Ltd, Australia

${ }^{*}$ Correspondence:

Mijail Karpyn Esqueda

Mijail.Karpyn@ecodev.vic.gov.au

Simone Rochfort

Simone.Rochfort@ecodev.vic.gov.au

Specialty section:

This article was submitted to

Plant Biotic Interactions,

a section of the journal

Frontiers in Plant Science

Received: 01 June 2016 Accepted: 03 January 2017 Published: 19 January 2017

Citation:

Karpyn Esqueda M, Yen AL, Rochfort S, Guthridge KM, Powell KS,

Edwards $J$ and Spangenberg GC (2017) A Review of Perennial Ryegrass Endophytes and Their Potential Use in

the Management of African Black Beetle in Perennial Grazing Systems in Australia. Front. Plant Sci. 8:3. doi: 10.3389/fp/s.2017.00003

\section{A Review of Perennial Ryegrass Endophytes and Their Potential Use in the Management of African Black Beetle in Perennial Grazing Systems in Australia}

\author{
Mijail Karpyn Esqueda ${ }^{1,2,3 *}$, Alan L. Yen ${ }^{1,2,3}$, Simone Rochfort ${ }^{1,2,3 *}$, \\ Kathryn M. Guthridge ${ }^{1,2}$, Kevin S. Powell ${ }^{4}$, Jacqueline Edwards ${ }^{1,3}$ and \\ German C. Spangenberg $1,2,3$
}

\footnotetext{
${ }^{1}$ AgriBio, Department of Economic Development, Jobs, Transport and Resources, Centre for AgriBioscience, Agriculture Victoria, La Trobe University, Melbourne, VIC, Australia, ${ }^{2}$ Dairy Futures Co-operative Research Centre, Melbourne, VIC, Australia, ${ }^{3}$ School of Applied Systems Biology, La Trobe University, Melbourne, VIC, Australia, ${ }^{4}$ Agriculture Victoria, Department of Economic Development, Jobs, Transport and Resources, Rutherglen, VIC, Australia
}

The major insect pest of Australian cool temperate pastures is the root-feeding insect Heteronychus arator (African black beetle, ABB). Significant pasture damage can occur even at low ABB densities (11 individuals per square meter), and often re-sowing of the whole paddock is required. Mitigation of the effects of pasture pests, and in particular subterranean species such as the larval form of ABB, can be challenging. Early detection is limited by the ability to visualize above-ground symptoms, and chemical control of insects in soil is often ineffective. This review takes a look at the historical events that molded the pastoral landscape in Australia. The importation route, changes in land management and pasture composition by European settlers may have aided the establishment of ABB in Australia. Perennial ryegrass Lolium perenne is discussed as it is one of the most important perennial agricultural grasses and is widely-sown in moderate-to-high-rainfall temperate zones of the world. Endophytic fungi from the genus Epichloë form symbiotic relationships with cool season grasses such as Lolium perenne (perennial ryegrass). They have been studied extensively and are well documented for enhancing persistence in pasture via a suite of bioactive secondary metabolites produced by the fungal symbionts. Several well-characterized secondary metabolites are discussed. Some can have negative effects on cattle (e.g., ergovaline and lolitrems) while others have been shown to benefit the host plant through deterrence of insect pests from feeding and by insecticidal activity (e.g., peramine, lolines, ergopeptines). Various control methods for ABB are also discussed, with a focus on the potential role of asexual Epichloë endophytes.

Keywords: endophyte, Heteronychus arator, pasture, pest management, control methods 


\section{INTRODUCTION}

Food production is a basic requirement for a sustainable society and the reason why a significant area of land has been dedicated to agricultural practices worldwide. Within these practices, part is devoted to animal production systems as grassland for grazing animals and hay production (Conant et al., 2001). Although annual grasses and food crops have been selected for their productivity since the beginning of agriculture, perennial grasses have only been studied in the last century (Wilkins, 1991). The domestication and expansion of grasses have been associated with the early stages of primitive agriculture in the Fertile Crescent of the Middle East about 10,000 years ago (Balfourier et al., 2000). This scenario suggests that ryegrasses were probably spread as weeds of cultivated crops by farmers during migratory events.

It has been predicted that the world population will increase by $50 \%$ between 2000 and 2050 to nine billion people (KingstonSmith et al., 2013). Pastures play an important role in agriculture as production of meat and milk products increases to supply the growing human population (Lasley et al., 2009). This represents a challenge for agronomists, as they will have to achieve the right balance for sustainable production, one that does not compromise food quality or the environment (Tilman et al., 2002). Ruminants are vital for mankind as they provide high protein food products from plant material that is otherwise unsuitable for humans (Kingston-Smith et al., 2013). Finneran et al. (2012) highlighted the importance of determining the annual cost of feed in order to achieve a self-sustainable grassland system, therefore decreasing the purchase of concentrated feed and increasing profitability. Additionally, a better understanding of the nutritional requirements of ruminants has allowed for an improvement in the quality of forage crops grown on pasture land, which has translated into improved animal performance (Kingston-Smith et al., 2013).

However, growers face biotic (invertebrate pest, plant pathogens, and weeds) and abiotic (temperature, water, soil type, and nutrients, etc.) stressors that can severely reduce crop production; some of these biotic factors can be managed by physical (cultivation, mechanical weeding, etc.), biological (cultivar choice, crop rotation, predators, etc.) and chemical measures (pesticides, herbicides, Oerke, 2006). This review focuses on the control methods for the economically important insect pest, the African black beetle (Heteronychus arator) primarily focusing on the use of perennial ryegrass endophytes. Physical, biological, and chemical measures described by Oerke (2006) are explained here in terms of cultural control methods, natural predators and parasites, and chemical control. This review also includes a background on the beginnings of agriculture in Australia and a sequence of events that has led to the current pasture-based grazing systems for animal production.

\section{EARLY HISTORY OF GRAZING IN AUSTRALIA}

The pastoral industry began in Australia at the time of European settlement. The first livestock to be introduced were bought from
South Africa in 1787 and later transported to Australia (Clark, 1962). Due to the poor soil conditions and harsh grasses at the harbor side in Sydney the establishment of an agriculture enterprise was difficult (Younger, 1993). Initially, animals grazed on the cove of Port Jackson but were then moved to the head of the next cove after exhausting the limited feed in the area (Taylor, 1982). Even though early reports mentioned that most of the livestock imported survived after 6 months in Australia, all six cows and two bulls went missing after being left unattended (Younger, 1993). Food shortages and the lack of animals catalyzed the search for fertile soil leading to the settlement of the Rosehill area, $25 \mathrm{~km}$ west of Port Jackson, later that year (Hill, 2008).

In 1795, wild cattle were sighted in increasing numbers at the west bank of the Nepean River which were thought to be related to the cattle that escaped in the earlier years of the colony (Younger, 1993). It was not until 1803, however, that the government declared that the cattle could be maintained and numbers increased sustainably without relying on importation (Alexander and Williams, 1973).

Advances in food production were repeatedly affected by a series of droughts and insect plagues in 1810 forcing the colony to rely on imports from India, and in 1816 from Van Diemen's land (now Tasmania) (Stone and Garden, 1978). Food demand became a major concern as the number of convicts sent to Australia rapidly increased (Stone and Garden, 1978). Around 1820 , meat production was the main focus for stockmen and other products, such as wool, were not as important at the time (Alexander and Williams, 1973). During the following years the agricultural industry experienced an expansion enabled by the convict system that provided cheap labor and inexpensive tracks of land (Stone and Garden, 1978). The earliest records of the dairy industry date back to the 1820 s when dairy herds began to appear in the Illawarra district, New South Wales (Drane and Edwards, 1961).

The growth of the agricultural industry and the increase in investment allowed the establishment of the Australian Agricultural Company in 1824, which had large capital and land grants for expansion (Stone and Garden, 1978). The rapid expansion of the industry led to exploitation and grazing on unoccupied lands beyond the settlement boundaries despite the Governor's efforts (Billis et al., 1930; Alexander and Williams, 1973).

\section{SEQUENCE OF AGRICULTURAL DEVELOPMENTS}

Between 1830 and 1860, the Sydney-based colony expanded in all directions including southern Queensland, parts of the Riverina and across the Murray, Port Phillip, Adelaide, Swan River, and Albany in Western Australia (Pearson and Lennon, 2010). Agriculture in Australia suffered its ups and downs during this period. In the early 1840's an Australia-wide depression took place after a drop in prices of the main commodities at the time (wool and meat) due to a surplus of livestock (Alexander and Williams, 1973). During the gold rush in 1851, the pastoral 
industry was initially detrimentally affected but then bounced back due to the high demand for meat caused by the increase of migration into the country (Pearson and Lennon, 2010). Fencing and management of native and introduced pastures also came into practice during the acute labor shortage caused by the goldrush (Schofield, 1990).

With the rapid expansion of the cities, dairy herds were established to supply the locality with milk (Alexander and Williams, 1973). The location of dairy farms was determined by a range of factors including climate, topography but more importantly a nearby market (Drane and Edwards, 1961). To be able to provide milk twice a day to the nearby city, dairy farms required a high rainfall and a long growing season to favor introduced pastures such as perennial ryegrass (Lolium perenne), white clover (Trifolium repens, T. pretense) and prairie grass (Ceratochloa unioloides) (Alexander and Williams, 1973).

Until the 1880s, dairying remained a local industry as markets had to be near enough to enable the product to be transported before it spoiled (Drane and Edwards, 1961). In areas of high rainfall located away from the cities, cattle were kept for cheese and butter production (Alexander and Williams, 1973). Between 1880 and 1900, major technological advancements-including refrigeration for shipping, the Babcock system of estimating fat content of milk, and factory methods for manufacturing and preserving dairy products-allowed the rapid expansion of the dairy industry (Drane and Edwards, 1961).

From 1900 to the present time, the pastoral industry has gone through some challenging times: drought (1900), World War I (1910-1914), the Great Depression (1930-1940s), World War II (1939-1945), and recession (1990s) (Pearson and Lennon, 2010). During this period, however, scientific research focused on the selection and improvement of exotic and native grass cultivars to increase productivity and expand agriculture to areas which had not been exploited before (Parbery, 1967). In recent decades, the Australian industry has faced significant structural adjustment which has transformed the industry, driving productivity, and growth (Stott and Gourley, 2016). Milk production has intensified, with fewer farms and increased stocking rates, and there have been substantial increases in the use of bought-in feed and nitrogen $(\mathrm{N})$ fertilizer to support increased milk production per cow and per hectare (CIE, 2011).

Currently agriculture makes a significant contribution to the Australian economy both nationally and in regional areas. The value of farm production was almost \$54 billion in 2013-14. Agriculture contributed around 2\% of Australia's Gross Domestic Product with milk being the third highest commodity (See Figure 1) (ABARES, 2014).

Dairy farming relies on high quality permanent pastures for year-round grazing (Stott and Gourley, 2016). Pastures are typically dominated by perennial ryegrass (Lolium spp.) and varying proportions of legumes (e.g., clover, Trifolium spp., Chapman et al., 2008; Jacobs, 2014).

\section{AUSTRALIAN PASTURES}

Prior to European settlement, extensive areas of vegetation were present either as grassland or as the understorey to Eucalyptus woodland in the south-eastern part of the continent (Groves et al., 2003). The typical plant composition of temperate grassland areas included perennial tussock, inter-tussock herbaceous flowering plants, with Themeda, Poa, and Austrodanthonia as the dominant grass genera (Lunt and Morgan, 2002). Vast areas of the temperate zone of south-eastern Australia had a long history of Aboriginal management before the first European settlers arrived on the continent (Gott, 2005).

Examples of land management by aboriginal people have been found in written reports of the earliest explorers:

\begin{abstract}
"I found a considerable store of grass-seed, gum from the Mimosa, and other stores, carefully packed up in bags made from the skin of the kangaroo, and covered over with pieces of bark, so as to keep them properly dry. The weight of the bags containing the grass seed and gum was about $100 \mathrm{lbs}$; the seeds had been carefully dried after being collected from small grasses of the plains" (Coxen, 1866)

"Dry heaps of this grass, that had been pulled expressly for the purpose of gathering the seed, lay along our course for many miles" (Mitchell, 1848)
\end{abstract}

Additionally, Aboriginal people used fire to clear tracks and open hunting grounds (Rolls, 1999). It is no surprise that the temperate zone overlapped with the areas in which colonizers established and expanded their settlements (Pearson and Lennon, 2010). The extent of the temperate zone in the southern part of the continent incorporates Tasmania, most of Victoria, eastern NSW, areas of southern South Australia and the south-west of Western Australia (Dorrough et al., 2004). The European settlers exploited the fertile plains first, altering the native ecosystem to pasture and crops through agricultural practices (Lunt, 1991). Permanent changes in the vegetation composition such as pastures have occurred in response to the prolonged and intensive grazing (Groves et al., 2003). Large-scale conversion of grassland and grassy woodland to exotic pastures and crops took place on the fertile soils of south-eastern Australia as part of the colonization process (Fensham, 1998).

From the historical data we can appreciate how the improvement of pastures became an imperative in order to aid agricultural industries. The introduction of a number of plant species were promoted by the Acclimatisation societies, in conjunction with government botanists, during the late $1800 \mathrm{~s}$ (Cook and Dias, 2006). Perennial pastures were first introduced into field trials in Victoria in 1860, as an initiative of the state government, with the purpose of evaluating the introduction and naturalization of pasture species (Cunningham et al., 1994). Perennial ryegrass was later reported as naturalized in Victoria before 1878 (Laffan and Ashton, 1964). Some studies date back to 1928 in Burnley, Victoria, when some pasture species were introduced and naturalized for agricultural purposes (Beilharz and Halloran, 1987). However, as pasture improvement moved further inland into drier regions the standard cultivars began to fail (Reed and Cocks, 1982).

In the 1950s, there was a large effort to develop perennial grass cultivars for the hotter, drier areas of south-eastern Australia. Grasses that could persist in a Mediterranean climate (average annual rainfall $<400 \mathrm{~mm}$ ) were collected from Southern Europe 


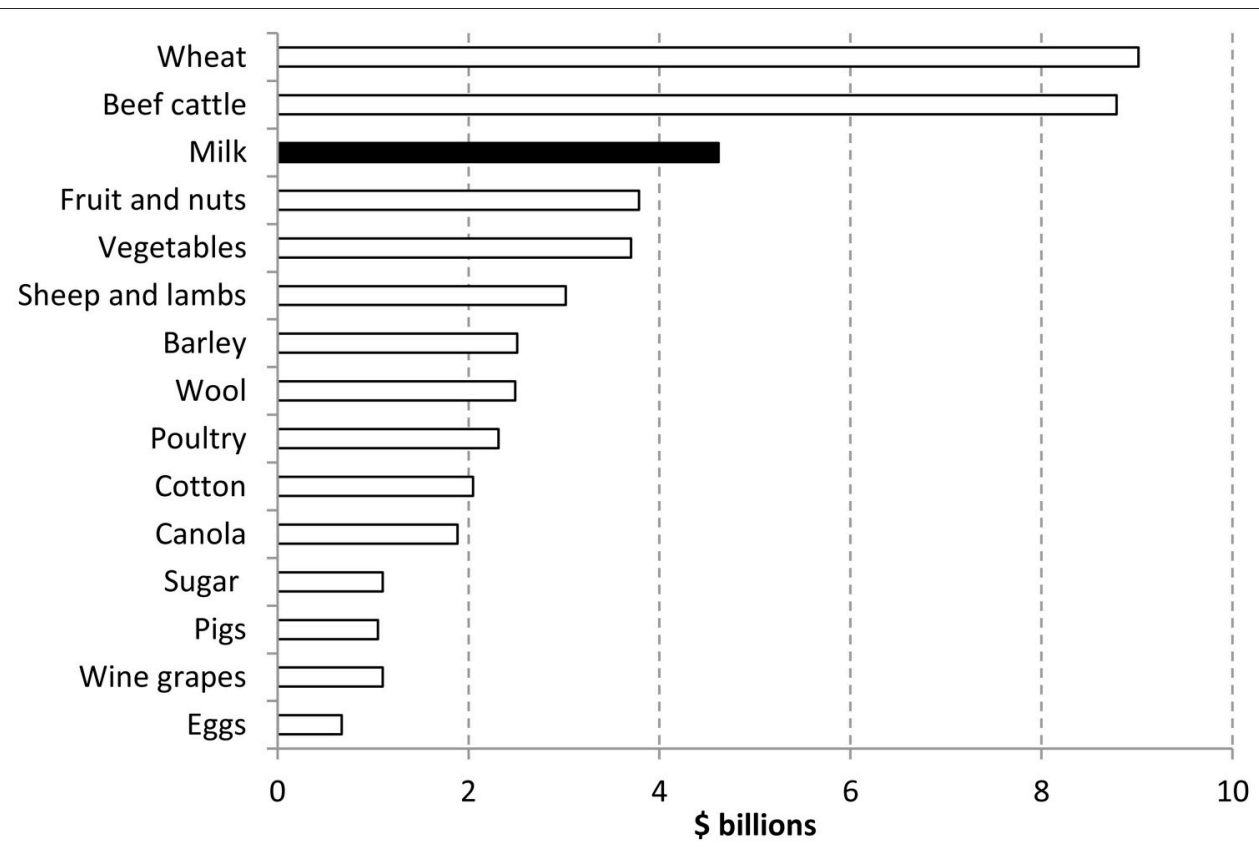

FIGURE 1 | Contribution of agriculture sectors in Australia 2013-2014 (ABARES, 2014).

and North Africa in order to provide new germplasm for breeding programs (Clark et al., 2016).

Cunningham et al. (1994) describes improvement programs of perennial ryegrass in Australia (1936-1995) from which different grass cultivars were developed and certified regionally (Victoria, New South Wales, Tasmania and South Australia) with the objective of improving their persistence, resistance to biotic and abiotic factors and quality.

More recently, in 1994, a joint effort by the Victorian Department of Agriculture, the U.S. Department of Agriculture and agencies in Morocco, Tunisia, and Italy collected widely in those three countries (Cunningham et al., 1997). Among the species collected were tall fescue, perennial ryegrass, phalaris and cocksfoot (Reed et al., 2016).

\section{PERENNIAL RYEGRASS}

Perennial ryegrass (Lolium perenne) is one of the most important perennial agricultural grasses world-wide. It is native to Europe, temperate Asia, and North Africa (Jensen et al., 2001) but it has been introduced in many countries including New Zealand, United States, and Australia for agricultural uses (Cunningham et al., 1994; Easton et al., 2001; Young et al., 2013), where it is widely-sown in moderate-to-high-rainfall temperate zones. Perennial ryegrass is an ideal forage grass due to its high digestibility, tolerance to grazing, and adequate seed production (Frame, 1989; Wilkins, 1991). Additionally, it is highly adaptive to different habitats and there is significant variation of traits in the wild populations providing room for genetic improvement (Wilkins, 1991).

There are three key factors that agronomists look to improve when breeding perennial ryegrass: dry matter yield, forage quality and persistence (temperature, drought, pests, disease, etc.) (Humphreys et al., 2006). As in most cool-season grasses, perennial ryegrass is an obligate outbreeder or self-incompatible plant that suffers from inbreeding depression (Cunningham et al., 1994). Self-incompatibility (SI) has been defined by Denettancourt (1977) as "the inability of a fertile hermaphrodite seed plant to produce zygotes after self-pollination." Husband and Schemske (1996) defined inbreeding depression as "the reduction in fitness of progeny derived from inbreeding relative to those derived from outcrossing." The SI mechanism in grasses hinders the production of inbred lines and hybrids in plant breeding, but also preserves heterozygosity in wild populations (Yang et al., 2008).

The obligate outbreeding nature of perennial ryegrass is why the initial advancements in breeding programs were performed by gene selection through sexual recombination (Humphreys et al., 2006). Continuous selection of full or half-sibling families allows for the improvement of pastures as desirable traits are assessed after each generation but progress is rather slow (Wilkins, 1991).

Another factor taken into account in perennial ryegrass breeding programs is the presence of asexual Epichloë endophytes because of the benefits of this symbiosis to the host plant (Funk and White, 1997). Elite cultivars obtained from breeding programs are combined with selected asexual Epichloë endophyte strains which can be incorporated into grass plants by inoculation (Funk and White, 1997).

\section{FUNGAL ENDOPHYTES}

Epichloë (syn. Neotyphodium) spp. have been described in early publications as endophytic fungi present in grasses such 
as perennial ryegrass and tall fescue (Sampson, 1933). They are an important group of filamentous fungi that infect cool season grasses, and consist of sexual (Epichloë) and asexual (Neotyphodium) species, previously classified as Acremonium sect. Albo-lanosa (Glenn et al., 1996). However, recent changes in fungal nomenclature rules have led to the renaming of the asexual (anamorphic) and sexual (teleomorphic) taxa into a single genus, designated Epichloë (Leuchtmann et al., 2014). The asexual growth of Epichloë endophytes in host grasses is characterized by seldom-branching hyphae in leaf sheaths which, in most cases, is aligned parallel to the leaf axis (Christensen et al., 2002). The endophyte is vertically transmitted through seeds by colonizing the developing flowers, ensuring their continuity from mother to daughter plant (Schardl, 1996). However, if the sexual stage of Epichloë species occurs, fungal stromata are formed on immature inflorescences "choking" affected flowering tillers and rendering them sterile (Moon et al., 2000).

The presence of asexual Epichloë endophytes in cool season grasses is not apparent and plants remain symptomless (Sampson, 1933; Wilson, 1993; Clay and Schardl, 2002; Iannone et al., 2011). However, infected plants can experience increased plant growth, reproduction and resistance to various biotic and abiotic stress factors (Clay and Schardl, 2002). For example, in symbiosis, Epichloë endophytes produce an array of secondary metabolites that benefit host plants through improved resistance against herbivores, pathogens, and drought (Siegel et al., 1987; Wilson, 1993; Zain, 2011). Christensen et al. (1993) demonstrated that alkaloid profiles are strain-specific producing the same chemical profile when the fungal symbionts are compared in the same plant. However, the chemical profile produced by an endophyte in symbiosis with a plant varies depending on the endophyte-plant combination (Panka et al., 2013). Evidence obtained from pot and field experiments have shown that endophyte-infected pastures perform better than endophyte-free swards under the above mentioned selective pressures (Prestidge and Gallagher, 1988b; Bacon, 1993; Crawford et al., 2010; Saikkonen et al., 2013).

Even though alkaloids produced by the endophytes can be beneficial for their host plant, they are also known to cause harm to vertebrate herbivores including livestock (Fletcher and Harvey, 1981; Crawford et al., 2010). Some groups of alkaloids have been identified as harmful, for example ergopeptine (ergovaline) and isoprenoid lolitrem (lolitrem B) which cause fescue toxicosis and ryegrass staggers, respectively (Smith et al., 1997). The effects of the different beneficial and harmful groups will be discussed in more detail in the section "Endophyte as a control method." These bioactive properties have driven research on the alkaloids produced by endophytic fungi because of the services they provide to their host plant and agricultural systems (Table 1).

\section{PASTURE PESTS}

Invertebrate activity can severely affect pastures by decreasing growth and establishment rate, impacting pasture composition favoring less palatable species and weeds, and enhancing damage caused by vertebrate grazers and predators by exposing areas to soil erosion (Bailey, 2007). However, some invertebrates which play a role in promoting pasture health (e.g., earthworms, termites, and ants) are regarded as soil engineers (Jouquet et al., 2006). Invertebrates that participate in biological, chemical and physical processes providing soil ecosystem services (e.g., recycling of nutrients, control of local microclimate, regulation of local hydrological processes, regulation of the abundance of undesirable organisms, and detoxification of noxious chemicals) as well interacting with other organisms in the substrate are recognized as beneficials (Altieri, 1999; Lavelle et al., 2006). It has been suggested that loss of biodiversity can prove costly for agroecosystems, as this directly affects basic regulation processes including soil fertility and pest control (Altieri, 1999).

In Australia, changes in land use from native pasture to intensive agriculture with exotic temperate pasture grass and legume species has led to addition of fertilizer and superphosphates to the soil to sustain such practices (King and Hutchinson, 1983). These landscape modifications have been associated with improved livestock production; however they also affect soil structure, water and nutrient cycling, as well as pasture productivity and palatability (Dorrough et al., 2004). Introduced pasture species influence their landscape by decreasing biodiversity of vegetation and invertebrate communities (King et al., 1985). In this large-scale intensive agriculture model, there is an increasing dependency on chemicals to manage pests which differs from the concept of sustainable agriculture (Tilman et al., 2002; Tscharntke et al., 2005).

European studies have found that improvement and management of pasture affects abundance and species richness of predators such as carabid beetles and spiders. Frequent use of the organo-phosphate pesticide chlorpyrifos was singled out as an important factor affecting predator richness (Rushton et al., 1989). In addition to the application of pesticides, grazing pressure has shown to have an impact on arthropod diversity of predator species (e.g., spiders) as well as affecting the abundance and diversity of pollinators such as bumblebee species (Tallowin et al., 2005).

In Australia there has been less research on the effect of agriculture on insect pollinators. Broad scale agriculture is thought to be associated with a low density of native bees, probably due to the absence of diverse nectar producing flowers, whereas the impact of pesticides on native bees is thought to play a more minor role as it is not well understood (Batley and Hogendoorn, 2009). Application of pesticides in perennial crops systems can be disruptive for beneficial insects, which is why refugia outside treated areas are essential (Landis et al., 2000). European studies suggest that mitigation of the negative effects of land management can be achieved by providing refugia adjacent to farmland to encourage the survival and reproduction of invertebrate predators (Macleod et al., 2004); changing grazing regimes to support beneficial species (Tallowin et al., 2005) and; reducing chemical sprays that impact on invertebrate predators (Rushton et al., 1989).

Although the relevance of European research to an Australian context is uncertain, Nash et al. (2008) found evidence to support transferability of some of this knowledge to Australian 
TABLE 1 | Chronology of some of the papers published on ryegrass endophytes.

\begin{tabular}{|c|c|c|}
\hline Subject & Research description & Reference \\
\hline \multirow[t]{5}{*}{ Animal health } & Association of Lolium endophyte with ryegrass staggers. & Fletcher and Harvey, 1981 \\
\hline & Isolation of stagger-producing neurotoxins lolitrem $\mathrm{A}$ and $\mathrm{B}$. & Gallagher et al., 1981 \\
\hline & $\begin{array}{l}\text { Evaluation of the effects of penitrem, paxilline, and lolitrem B on sheep smooth muscle, show they } \\
\text { cause low, mild, and persistence tremors, respectively. }\end{array}$ & Smith et al., 1997 \\
\hline & $\begin{array}{l}\text { Review of mycotoxins important in ruminant feeding such aflatoxins, lolitrems, ergopeptine } \\
\text { alkaloids, and others produced by fungi that are found in cattle feed. }\end{array}$ & D’Mello and MacDonald, 1997 \\
\hline & $\begin{array}{l}\text { Evaluation of novel (AR37 and AR1) ryegrass endophytes showed improved persistence against } \\
\text { insect pests without affecting cattle health. }\end{array}$ & Thom et al., 2013 \\
\hline \multirow[t]{7}{*}{ Insect } & $\begin{array}{l}\text { Endophytes producing alkaloids responsible for ryegrass staggers in lambs (i.e., lolitrem B) were } \\
\text { found to affect the growth rate of Argentine stem weevil (Listronotus bonariensis) larvae. }\end{array}$ & Prestidge and Gallagher, 1988a \\
\hline & $\begin{array}{l}\text { Pot trials show that endophyte positive plants were significantly less damaged than endophyte free } \\
\text { controls regardless of their alkaloid spectra. }\end{array}$ & Ball et al., 1994 \\
\hline & $\begin{array}{l}\text { Bioassay based on mycotoxins found that only certain ergopeptine alkaloids deter adult African } \\
\text { black beetle in vitro. }\end{array}$ & Ball et al., 1997b \\
\hline & $\begin{array}{l}\text { Absence of synergism between endophyte-infected perennial ryegrass and Paenibacillus popilliae } \\
\text { against Japanese beetle (Popillia japonica). }\end{array}$ & Walston et al., 2001 \\
\hline & $\begin{array}{l}\text { Pot trials found no effect of endophyte-infected ryegrass on redheaded (Adoryphorus coulonii) and } \\
\text { blackheaded (Acrossidius tasmaniae) pasture cockchafers. }\end{array}$ & Watson, 2006 \\
\hline & $\begin{array}{l}\text { Field trials examining the effects of selected endophyte strains (AR1 and AR37) and control against } \\
\text { insect pests. }\end{array}$ & Popay and Thom, 2009 \\
\hline & $\begin{array}{l}\text { Evidence of peramine and lolitrem B cascading up the food chain from aphids to ladybird increasing } \\
\text { the duration of the pupal stage. }\end{array}$ & Fuchs et al., 2013 \\
\hline \multirow{2}{*}{ Plant performance } & $\begin{array}{l}\text { Grass-endophyte associations are based primarily on protection of the host from biotic and abiotic } \\
\text { stresses. }\end{array}$ & Clay and Schardl, 2002 \\
\hline & Endophyte-infected plants promoted competitiveness, hindering weed invasion. & Saikkonen et al., 2013 \\
\hline
\end{tabular}

agricultural systems in regards to conservation of predatory invertebrates. An Australian research team, Tsitsilas et al. (2006), highlighted that grassy shelterbelts adjacent to pasture may influence the number of pest organisms. More importantly, these shelterbelts carried low numbers of pest species but higher numbers of predatory mites and spiders. Collins et al. (2002) found that although refugia within a crop field (in this study refered to as beetle banks) supported polyphagous predators, they failed to prevent aphid outbreaks; the presence of refugia did appear to have a significant impact on reducing the aphid population up to a distance of $83 \mathrm{~m}$ from the refuge. Collins et al. (2002) concluded that to prevent economic losses, optimal density of predators and spacing of refugia in fields must be determined.

Australia's major pest groups of grass pastures and turf have been well described by Bailey (2007), who provides detailed information about the pest's food source and some of the different control methods available (Table 2).

Historically, pasture pests have taken a toll on Australian agriculture from as early as 1810 when caterpillar plagues and drought severely affected pastures (Stone and Garden, 1978). Hoffmann et al. (2008) reviewed pest outbreak bulletins from the 1980-1984, 1985-1989, 1990-1994, and 2006-2007 from southeastern Australia and reported that the relative incidence of 
TABLE 2 | Major pest groups of grass pastures and turf in Australia, adapted from Bailey (2007).

\begin{tabular}{|c|c|c|}
\hline Pest & Common name & Scientific name \\
\hline \multirow[t]{5}{*}{ Mites (Acari) } & Cereal rust mite & Abacarus hystrix \\
\hline & Blue oat mites & Penthaleus spp. \\
\hline & Red legged earth mite & Halotydeus destructor \\
\hline & Bryobia pasture mite & Bryobia praetiosa \\
\hline & Balaustium mite & Balaustium medicagoense \\
\hline Springtails (Collembola) & Lucerne flea & Sminthurus viridis \\
\hline \multirow[t]{2}{*}{ Snails and slugs (Mollusca) } & Common garden snail & Cantareus aspersa \\
\hline & Slugs & Eupulmonata \\
\hline \multirow[t]{10}{*}{ Caterpillars (Lepidoptera) } & Black cutworm & Agrotis ipsilon \\
\hline & Corbie & Oncopera intricate \\
\hline & Winter corbies & O. rufobrunnea \\
\hline & $\begin{array}{l}\text { Underground } \\
\text { grassgrubs }\end{array}$ & O. fasciculate \\
\hline & Ghost moths & Fraus simulans \\
\hline & Oxycanus grassgrub & Oxycanus antipoda \\
\hline & Armyworms & Leucania spp. \\
\hline & Pasture webworms & Hednota spp. \\
\hline & Cotton webspinner & Achyra affinitalis \\
\hline & Pasture tunnel moths & Philobota spp. \\
\hline \multirow{3}{*}{$\begin{array}{l}\text { Crickets and Grasshoppers } \\
\text { (Orthoptera) }\end{array}$} & Black field cricket & Teleogryllus commodus \\
\hline & Mole crickets & Gryllotalpa spp. \\
\hline & $\begin{array}{l}\text { Wingless } \\
\text { grasshoppers }\end{array}$ & Orthoptera: Acrididae \\
\hline \multirow[t]{5}{*}{ Beetles (Coleoptera) } & African black beetle & Heteronychus arator \\
\hline & $\begin{array}{l}\text { Blackheaded pasture } \\
\text { cockchafer }\end{array}$ & Acrossidius tasmaniae \\
\hline & $\begin{array}{l}\text { Redheaded pasture } \\
\text { cockchafer }\end{array}$ & Adoryphorus coulonii \\
\hline & Argentine stem weevil & Listronotus bonariensis \\
\hline & White fringed weevil & Naupactus leucoloma \\
\hline
\end{tabular}

lucerne flea, Balaustium mites, blue oat mites, redlegged earth mites, snails, and pasture cockchafers had increased during that period.

Scarabaeidae is one of the largest families of Coleoptera in Australia, comprising seven subfamilies and 3000 species (Allsopp, 1995). A number of these species are pasture beetles that share a similar lifestyle and behavior. For quite some time, all scarab larvae were commonly referred as "white grubs" because of their white/creamy color and curled shape during the larval stage (Cumpston, 1940). Members of the subfamilies Dynastinae, Rutelinae, and Melolonthinae are generally soildwelling, phytophagous, or phytosaprophagous, and in some cases the adults do not feed (Allsopp, 1995). However, there are still a number of soil-inhabiting pasture beetles whose larval forms have not yet been described (Berg et al., 2014). Pasture beetle larvae are predominantly a problem in grassland areas where they feed on humus and plant roots, decreasing plant persistence dramatically under stress conditions (e.g., grazing livestock, use of machinery, Blank and Olson, 1988; Berg et al., 2014). Some of the most cited crop and pasture pests in Australia from this family are summarized in Table 3. Most of these pasture beetles are endemic to Australia but that is not the case for the African black beetle, which, as its common name suggests, originates from Africa (Matthiessen and Ridsdill-Smith, 1991).

\section{AFRICAN BLACK BEETLE}

African black beetle (Heteronychus arator) is a univoltine (1 year life cycle) soil-dwelling scarab beetle predominately found in grassland (Matthiessen, 1999; Bell et al., 2011). Temperature seems to affect, directly or indirectly, the presence and distribution of African black beetle, as its incidence has been associated with areas with mean annual surface temperatures greater than $12.8^{\circ} \mathrm{C}$ (Watson, 1979). African black beetle is recognized as an agricultural pest in Australia, New Zealand, and South Africa (Matthiessen and Learmonth, 1998). The earliest record of its introduction in Australia is a specimen collected in Newcastle, NSW, in 1920, but it is presumed to have become established prior to 1920 (Wright, 1958). The earliest record in the Australian Pest Plant Database dates back to 1930 (Plant Health Australia, 2001), similar to the first reports in New Zealand in 1937 (Todd, 1959). In Australia, African black beetle has been reported throughout the coastal region of New South Wales, widespread in pastures of south-western Western Australia, in coastal South Australia, parts of Queensland, and Victoria (Plant Health Australia, 2001). Most of its lifecycle occurs underground, but during the adult stage, they emerge to mate and on some occasions swarm (Ormerod and Janson, 1889; Matthiessen and Learmonth, 1998; Bulinski et al., 2006). It has been suggested that flights not only occur to vary habitat between life stages, but also to have a dispersive role; as seen in most dynastids (members of the subfamily Dynastinae), flights are an adaptation to the fluctuation between seasons (i.e., wet and dry, as well as, cold and hot, Watson, 1979).

African black beetle is a polyphagous species, reported to affect a number of different plants such as, blue gum (Loch and Floyd, 2001), potatoes (Matthiessen and Ridsdill-Smith, 1991), tomatoes, grapevines (Bulinski et al., 2006), maize (Drinkwater, 2003), sugarcane, clover (Trifolium spp.), and grass species including, kikuyu, phalaris, Paspalum spp., and Lolium spp. (Bailey, 2007; Bell et al., 2011). Larvae feed on the roots (Bell et al., 2011) while adults have been reported to cause severe damage to subterranean stems of seedlings, including young stems of potatoes and summer-sown crops (Matthiessen and Ridsdill-Smith, 1991; Erasmus and Berg, 2014).

One of the reasons African black beetle is a difficult pest to control is because of its potential to cause a high level of damage per individual (Bulinski and Matthiessen, 2002). It has been suggested African black beetle can cause significant damage to crops at densities exceeding 10 individuals per square meter (Bailey, 2007). Densities of over 100 larvae per square meter can cause direct damage to turf grasses, however secondary damage caused by foraging birds preying on the grubs can be observed even at lower densities (Ford et al., 2001). 
TABLE 3 | Scarabaeidae pests of crops and pasture in Australia.

\begin{tabular}{|c|c|c|c|}
\hline Common name & Scientific name & Host plant & Reference \\
\hline African black beetle & Heteronychus arator & $\begin{array}{l}\text { Blue gum, potatoes, tomatoes, grapevines, } \\
\text { sugarcane, maize, kikuyu, phalaris, clover (Trifolium } \\
\text { spp.) and Paspalum spp. Lolium spp. }\end{array}$ & $\begin{array}{l}\text { Matthiessen and Ridsdill-Smith, 1991; Loch and } \\
\text { Floyd, 2001; Bulinski et al., 2006; Bailey, 2007; Bell } \\
\text { et al., } 2011\end{array}$ \\
\hline Redheaded cockchafer & Adoryphorus coulonii & Subterranean clover, annual and perennial grasses & Bailey, 2007; Berg et al., 2014 \\
\hline Blackheaded cockchafer & Acrossidius tasmaniae & Annual grasses, legumes and cereals & Mcquillan, 1985; Bailey, 2007 \\
\hline Yellowheaded cockchafer & Sericesthis harti & Pasture and cereals & Bailey, 2007 \\
\hline Wheat root scarab & S. consanguinea & Pasture and cereals & Bailey, 2007 \\
\hline Black beetle & Metanastes vulgivagus & Pasture and cereals & Bailey, 2007 \\
\hline Black soil scarab & Othnonius batesii & Pasture and cereals & Bailey, 2007 \\
\hline Cockchafer & Heteronyx obesus & Pasture and cereals & Bailey, 2007 \\
\hline
\end{tabular}

The African black beetle life cycle (Figure 2) starts in spring when the eggs are deposited, then the larvae go through three instars of development from around September-November to late summer when pupation takes place (Matthiessen and Ridsdill-Smith, 1991). Adults appear in numbers from March to September when mating and then oviposition occurs; adults die soon after reproduction (Matthiessen and Ridsdill-Smith, 1991). Flight dispersal mainly occurs during the autumn months by immature adults, while mature adults generally crawl during spring (Matthiessen and Learmonth, 1998). Autumn flights seem to be associated with the first significant rainfall after pupation, dusk surface temperatures $\left(>17^{\circ} \mathrm{C}\right)$ and favorable wind conditions (Watson, 1979). It has been suggested that flights during autumn and spring may play a crucial role in infestation of new pastures during outbreak years (Bell et al., 2011).

African black beetle was reported to be a serious crop pest in South Africa as early as 1889 (Ormerod and Janson, 1889). However, only two epidemic outbreaks (1946 and 1977) have been reported in South Africa, both in maize (Taylor, 1951; Drinkwater, 1979). African black beetle has been defined by King et al. (1981) as "a sporadic but serious pest of pastures and crops in northern areas of New Zealand's North Island." The incidence of some outbreaks has been associated with warm conditions cause by a La Niña weather pattern (Eden et al., 2011). Warm spring temperatures greatly benefit African black beetle populations by allowing early oviposition followed by rapid egg and larval development, therefore increasing survival over summer (East et al., 1981). In Australia, African black beetle had been reported to reach plague levels in New South Wales as early as 1923 and subsequently in 1929-1933, 1936, 1940, 1944-1946, 1952-1954, 1957 (Wright, 1958). Additionally, a more recent study of pest outbreak reports from 1980 to 20062007 revealed that the relative incidence of pasture cockchafers, including African black beetle, increased during that period (Hoffmann et al., 2008).

\section{CONTROL METHODS}

\section{Cultural Control Methods}

Cultural control methods refer to activities carried out to control one or more pests by changing the habitat conditions to promote biological control and/or decrease habitat quality for the pest (Horne and Page, 2008). As described in Bailey (2007), some cultural methods that could be used against African black beetle include: delaying sowing until November-December following the end of the beetles' life cycle; reducing potential habitat by removing grass and weeds from headlands; avoiding sowing in pasture areas that may contain adults; and establishing a physical barrier by cutting a deep furrow with a vertical side toward the crop. Some of the earliest remedies used to control African black beetle in South Africa included manure traps, sprinkling with salt, and application of lime into the soil, the latter being the only one reported as successful (Ormerod and Janson, 1889).

In Australia, some of the most productive agricultural land is naturally acidic (Scott et al., 2000). It has been suggested that addition of lime into soils with a naturally low $\mathrm{pH}$ may lead to local extinction of endemic acidophilic species, therefore its application must be treated with caution (Oliver et al., 2005). Furthermore, it is still unclear what effects lime applications might have on pasture cockchafers incidence and the host plant's ability to overcome feeding damage (Berg et al., 2014).

Several scarab species are considered significant pests of eucalypts (Frew et al., 2013). These include stem-feeders (Abbott, 1993) such as African black beetle (Paine et al., 2011) and common defoliators such as the Christmas beetles (Anoplognathus spp.) (Johns et al., 2004). It has been suggested that the use of fertilizer with nitrogen $(\mathrm{N})$ in eucalypt plantations could be used as a management option as it has been found to either moderate or negate the effect of severe insect defoliation on growth (Pinkard et al., 2006a). This is because the leaf structure and texture of eucalypts may play a role on levels of herbivory (Sanson et al., 2001; Steinbauer, 2001). For example, Pinkard et al. (2006b) showed that leaf density or thickness of Eucalyptus globulus increased following $\mathrm{N}$ application in response to artificial defoliation. Therefore, it has been argued that nitrogen $(\mathrm{N})$ application will not increase future herbivory problems (Pinkard et al., 2006a).

Nonetheless, irrigation and fertilization practices applied on eucalypt plantations have been positively correlated with an increase in scarab populations as these practices (mostly fertilization) also affect the understory (Frew et al., 2013). Therefore, even though fertilization with $\mathrm{N}$ prior to defoliation 


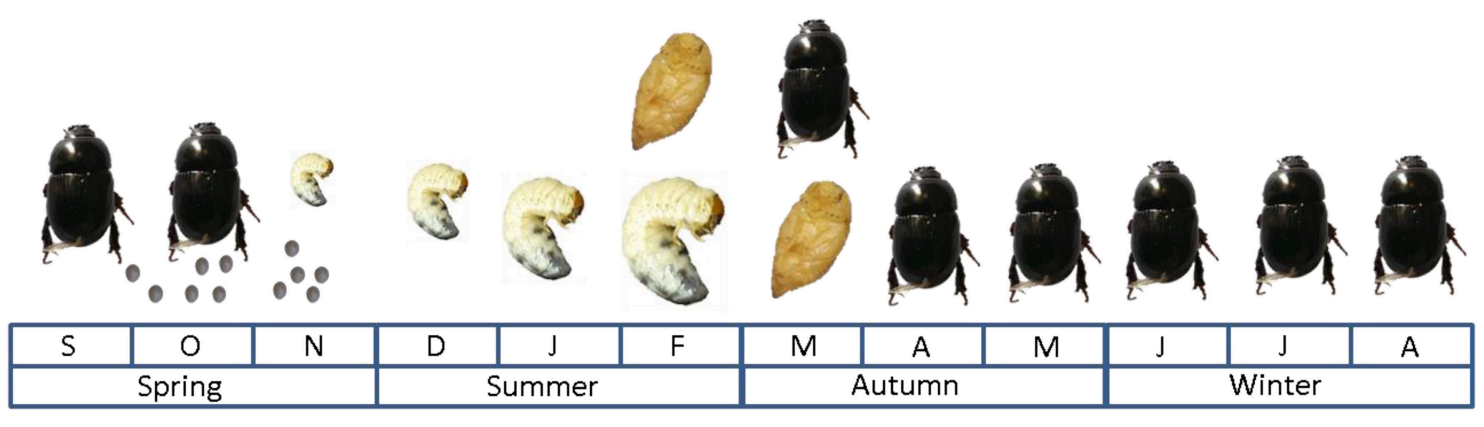

FIGURE 2 | African black beetle life cycle under Australian conditions as described by Matthiessen and Ridsdill-Smith (1991).

maintains stem growth and diameter at a similar rate to undefoliated unfertilized trees (Pinkard et al., 2007), it is concerning that the plantation understory of eucalypts and similar systems (e.g., orchards and oak woodlands) may serve as a potential niche for pasture beetles that will not only affect the plantation but also neighboring pastures and crops (Frew et al., 2013). Abbott (1993) highlighted that matforming grasses near plantations seem to favor African black beetle.

\section{MONOCULTURE EFFECTS}

Simplification of the environment on large expanses of land will cause an increase in the density of host plants, uniformity of crop population age structure and physical quality, and a decrease in biodiversity (Altieri et al., 1984). It has been suggested that pest problems in eucalypt plantations in south-western Australia may have been intensified by eucalypt monocultures (Loch and Floyd, 2001). Similarly, sown pastures are characterized by having lower diversity in vegetation and invertebrate communities than in naturally occurring pastures (King et al., 1985). In the case of pastures, it may be possible to break the lifecycle of the African black beetle through crop rotation; sowing non-host crops (e.g., brassicas, legumes, or chicory) in spring, thus causing a disruption of larval feeding as well as controlling grass weeds (Bell et al., 2011).

Even though evidence of monoculture effects has been found in agriculture (Altieri et al., 1984; Andow, 1991) this concept is not exempt from criticism (Emden and Williams, 1974; Goodman, 1975). Andow (1991) concludes that monocultures may influence pest abundance in different ways depending on the species (e.g., more in some, less in others) and that one hypothesis may not explain all insect-plant relationships. However, Root (1973) proposed two explanations for the monoculture effect and hypothesized that: (1) the level of complexity of the system is relative to the effectiveness of natural enemies to control herbivore populations (natural enemy hypothesis) and (2) specialized herbivores that can exploit the resources available in simple systems will reproduce in greater numbers than complex systems (resource concentration hypothesis). The facts that African black beetle is a polyphagous species (Bailey, 2007) and has the ability to disperse by flight (Matthiesse and
Learmonth, 1998) should be taken into account when developing a management plan, as surrounding areas could represent a potential habitat for harboring this insect pest (Frew et al., 2013).

\section{GRAZING}

Grazing is a naturally occurring event that has an effect on the botanic diversity and structure of an area; for this reason, grazing is considered as a potential management tool in grassland conservation (Tallowin et al., 2005). However, it is essential to be able to foresee how grazing can affect vegetation in order to increase spatial heterogeneity rather than decrease it (Adler et al., 2001). Continuous selective grazing by livestock gradually deteriorates the quality and composition of grassland as it can cause the loss of the most palatable species of sward (Dorrough et al., 2004). Ultimately, grazing can alter landscapes by inhibiting regeneration of woody trees and native vegetation (Bennett et al., 1994).

Overbeck (2014) found that the influence of grazing on vegetation richness is relative to the productivity of the site, whereby low-productivity sites experienced a decrease in vegetation richness while high-productivity sites experienced an increase in vegetation richness. On the other hand, the level of grazing pressure has been found to affect beneficial invertebrates (e.g., bumblebees and spiders), as their abundance and species richness decreases under severe grazing regimes (Luff and Rushton, 1989; Tallowin et al., 2005).

It has been argued that plant and structural diversity in agricultural landscapes positively affects the abundance and diversity of natural predators of invertebrates thus offering improved biological control (Fiedler et al., 2008; Woltz et al., 2012). However, lack of knowledge on the biology and ecology of such predators represents a limiting factor when incorporating them into a management program (Horne and Page, 2008).

Some recommendations on grazing management for pasture beetle prevention include reducing cattle numbers in the affected paddocks early in the year when damage is at its peak (Blank and Olson, 1988; Berg et al., 2014) and reducing ground cover for egglaying in early spring by heavy grazing and/or keeping pasture short (e.g., cut for silage, Douglas, 1972). 


\section{NATURAL PREDATORS AND PARASITES}

The presence of natural predators affects pest-host plant relationships by hindering pests, causing them to utilize unsuitable areas that are less productive, or even cease feeding/reproduction completely; as a result, the outbreak phase can be delayed by controlling population numbers when they are below plague levels (Riechert, 1999). It has been suggested that pest regulation by natural predators plays a key role in the prevention of pest outbreaks in sustainable agricultural systems (Kromp, 1999). East et al., 1981 argues that predators of scarab pests are frequently insignificant in improved grassland. However, removal of overgrown grass has been shown to increase larval predation by birds (e.g., starlings, East and Pottinger, 1975). In order to prevent economic losses, optimal density of predators and distribution of refugia in fields must be determined (Collins et al., 2002).

Arthropod predators known to prey upon African black beetle in its native range and also in other regions include scoliid and tiphiid (Hymenoptera), tachinid flies and a number of beetles belonging to the families Carabidae, Staphylinidae, and Elateridae (Cameron et al., 1979). However, only carabids of the genus Scarites have been found to be significant as their populations are more abundant and stable than some of the other predators (Valentine, 1979). Even though carabids are considered potential pest-control agents because of their wide range of prey (Kromp, 1999), we currently have limited knowledge on their ecology in Australia and how efficient they are at controlling particular pest species, including African black beetle (Horne and Page, 2008).

Some of the vertebrate predators that have been reported to consume African black beetle include the Amur falcon (Falco amurensis), lesser kestrel (Falco naumanni) (Pietersen and Symes, 2010), starling (Sturnus vulgaris) (East and Pottinger, 1975), Hadeda ibis (Bostrychia hagedash), the cattle egret (Bubulcus ibis), Guinea fowl (Numididae), moles and rodents (Valentine, 1979). There is a lack of information on the vertebrate predators of African black beetle in Australia but from some publications the straw-necked ibis (Thresbiornis spinicollis), white ibis (Threskiornis moluccus) (Carrick, 1959), the Australian magpie (Cracticus tibicen) and the Australian raven (Corvus coronoides) (Ford et al., 2001) have been cited to consume them in highly infested areas. Consequently these bird species are often used as a cue for selecting beetle sampling sites. In addition, foxes (Vulpes vulpes) at times heavily rely on insect consumption, but in these particular cases it is usually related to availability of the insect species or population levels; remains of pasture beetles Aphodius howitti and Rhopaea heterodactyla have been found in stomachs of several foxes (Coman, 1973). Similarly, from field observations, fecal pellets (which are believed to be from fox) containing the exoskeleton of the beetles have been found on paddocks where African black beetles were abundant. However, the effectiveness of biological control by these predators is limited to their abundance and to the areas in which they coexist with their prey (East and Pottinger, 1975). Moreover, vertebrate predators may cause damage to pastures (i.e., scratch the top soil) in order to locate and subsequently feed on scarab larvae (Georgis et al., 2006).

\section{ENTOMOPATHOGENS}

\section{Nematodes}

Entomopathogenic nematodes (EPNs) of the families Heterorhabditidae and Steinernematidae are often used as biological control agents of economically important insect pests due to the fact they are obligate parasites (Shapiro-Ilan et al., 2012). Unlike some parasitic nematodes, EPNs have a mutualistic relationship with pathogenic bacteria of the genera Photorhabdus for Heterorhabditidae, and Xenorhabdus for Steinernematidae (Lacey et al., 2001; Lewis et al., 2006). Both genera of symbiotic bacteria are motile and gram-negative Enterobacteria (Burnell and Stock, 2000). A number of pasture pests can be managed using nematodes including white grubs (Coleoptera: Scarabaeidae), mole crickets (Scapteriscus spp.), billbugs (Sphenophorus spp.), and the black cutworm (Agrotis ipsilon) (Georgis et al., 2006).

The process of infection is that juvenile nematodes seek out a suitable host to attach and penetrate (Lewis et al., 1993). Host penetration can occur through thin parts of the cuticle, spiracles (tracheae), mouth, and anus (midgut) (Koppenhöfer et al., 2000). The nematode-bacterial complex becomes lethal once it reaches the haemocoel, where the bacteria are released and multiply, killing the host within $48 \mathrm{~h}$ (Lewis et al., 1993; Lacey et al., 2001). When seeking potential pathogenic agents, Longworth and Archibald (1975) found that a nematode, Neoaplectana sp. (Steinernematidae), was present in African black beetle larvae.

However, there are a number of limitations for the use of EPNs as pest control agents. Factors that affect EPNs include accumulation of thatch in soil, soil temperatures below $20^{\circ} \mathrm{C}$, soil texture (fine is better), moisture retention, and irrigation (Georgis and Gaugler, 1991). At present the costs of using EPNs are much higher than those associated with use of commercially available chemical insecticides (Georgis et al., 2006), making them economically nonviable. It has been suggested that EPNs may play an important role in integrated pest management (IPM) in the future as insects become more resistant to pesticides (Lacey et al., 2001). There is evidence of synergism between imidacloprid and EPNs against third instar scarab larvae (Koppenhöfer et al., 2000). However, imidacloprid efficacy decreases against scarabs in the latter stages of larval development (third instar), which are known to cause the most damage (Lacey et al., 2001).

\section{Bacteria}

There are a number of potential bacterial control agents for insect pests of pastures.

\section{Bacillus thuringiensis}

Bacillus thuringiensis $(B t)$ is a gram positive spore-forming bacterium that has been widely suggested as a biological control agent against agricultural pests (Kati et al., 2007). The insecticidal properties of $B t$ are associated with Cry proteins ( $\delta$-endotoxins) which are synthesized as parasporal crystals during sporulation of the bacteria (Deml et al., 1999, Figure 3). Different varieties 


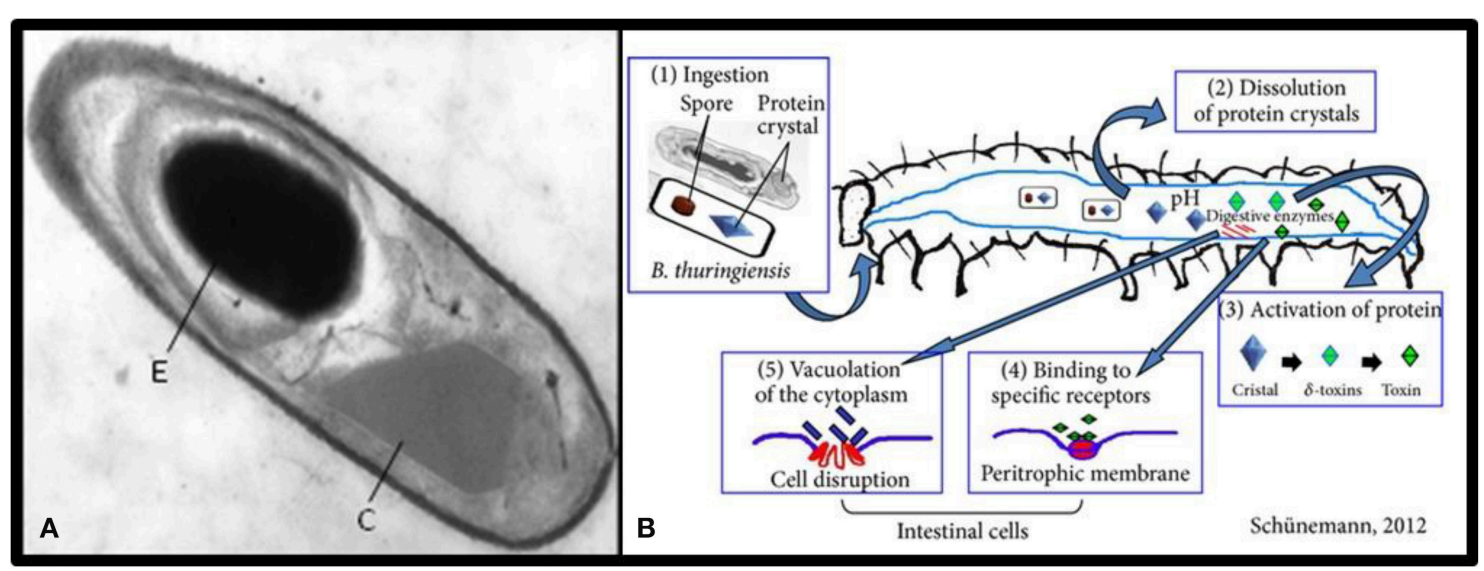

FIGURE 3 | (A) Transmission electron micrograph of a longitudinal section of Bacillus thuringiensis toward the end of sporulation; the spore (E) and the crystal inclusion (C) (Sanchis, 2010). (B) The mode of action of Bacillus thuringiensis (Schünemann et al., 2014).

of $B t$ produce different toxins that are specific to targets from Lepidoptera to Diptera and Coleoptera (Cidaria et al., 1991). Four major classes of insecticide crystal protein (ICP) genes have been identified: Lepidoptera-specific (CryI or Cry1), Lepidoptera- and Diptera-specific (Cryll or Cry2), Coleoptera-specific (CryIII or Cry3), and Diptera-specific (CryIV or Cry4) proteins (Chambers et al., 1991).

A study evaluating the effects of Bt-maize expressing Cry $1 \mathrm{Ab}$ on non-target species found that there was no effect on mortality, mass, fertility, or fecundity of Heteronychus arator and Somaticus angulatus (Coleoptera) (Erasmus and Berg, 2014). However, there is evidence of cross-order toxicities occurring on target species, for example, Cry1 Ab affecting mosquitoes Aedes aegypti (Diptera) (Haider et al., 1986), and CryIIIA having a comparable toxicity to CryIA in a number of caterpillars (Lepidoptera) (Deml et al., 1999). Van Frankenhuyzen (2009) highlighted that crossorder toxicities have been reported for 15 of the 87 insecticidal crystal protein families and that these numbers are likely to increase as testing across orders is expanded. Furthermore, $B t$ toxins have been found to affect mortality, development and longevity of parasitoid species that use target Lepidoptera as a host (Romeis et al., 2006).

Currently two methods are used to deliver $B t$ insecticidal proteins: formulated products prepared from naturally occurring or conjugated strains and development of transgenic plants which possess the genes responsible for the production of the toxin (Lacey et al., 2001). Some of the Bt-transgenic crops used include potatoes (Arpaia et al., 2000), eggplant (Arpaia et al., 2007), cotton (Sivasupramaniam et al., 2008), rice (Han et al., 2015), tobacco (Gore et al., 2005), and maize (Erasmus and Berg, 2014).

\section{Paenibacillus sp.}

Milky disease in scarab beetles receives its name from the milky aspect of the larva caused by a build-up of bacterial spores and parasporal bodies in the blood (Klein and Kaya, 1995). Milky disease comprises a number of species and strains of spore-forming rod bacteria which differ in morphology and virulence to specific hosts (Steinkraus and Tashiro, 1967). Milky disease bacteria can be found in scarab populations on all continents (Jackson and Klein, 2006). Paenibacillus popilliae and Paenibacillus letinmurbos (formerly Bacillus) are responsible for causing milky disease in Japanese beetle (Popillia japónica N.) and several other members of the scarab family (Dutky, 1940; Beard, 1956; Pettersson et al., 1999; Stahly et al., 2006). Bacterial spores are consumed by larvae while feeding on plant roots. Once the spores reach the gut, germination takes place followed by penetration of the haemocoel by vegetative cells (Harrison et al., 2000). Vegetative growing bacteria then sporulate in an asynchronous fashion leading to the death of the larvae (Rippere et al., 1998). Infectivity of $P$. popilliae varieties among scarabs tends to be higher in the species from which they were isolated (Klein and Kaya, 1995).

Dutky (1940) described the differences between the milky disease caused by Paenibacillus popilliae and Paenibacillus letinmurbos, describing them as type A and type B, respectively. Macroscopically they cannot be distinguished, however, the general appearance is quite different. In type A larvae tend to have a milk white coloration while in type B larvae turn muddy brown color. This coloration is due to the formation of haemolymph clots which block the insects' circulation resulting in gangrenous condition of the affected parts (Stahly et al., 2006).

Similar to Bt, $P$. popilliae produces parasporal crystals upon sporulation (Klein and Kaya, 1995; Deml et al., 1999). It has been suggested that parasporal crystal proteins may play a part in the mortality caused by milky disease because of the strong similarities and conservation of the hydrophobicity distribution of Cry proteins from Bt and P. popilliae (Zhang et al., 1997). While most of the insecticidal activity of $B t$ has been linked with the proteinaceous toxins located in parasporal inclusion bodies (parasporal crystals) (Lacey et al., 2001), P. lentimorbus causes a disease that is almost identical to that caused by $P$. popilliae, and has no parasporal inclusion (Stahly et al., 2006).

Despite the limitations of infectivity due to specificity from different varieties of $P$. popilliae (Klein and Kaya, 1995) this bacterium relies on the presence of viable spores to infect its 
host as vegetative cells experience a decrease of viability in soil as well as deficient virulence (Stahly and Klein, 1992). Similarly with Bt, Head et al. (2002) demonstrated that Cry proteins accumulated in soil due to the continuous use of transgenic $B t$ cotton are subsequently incorporated into the soil resulting in no detectable immunological and biological activity. Furthermore, other factors such as application of insecticides and fungicides have been shown to affect spore viability in soil (Dingman, 1994).

\section{Serratia sp.}

Bacteria which cause Amber disease have been mentioned in the literature as a potential biological control option for scarabs (Jackson and Klein, 2006). Serratia entomophila (Enterobacteriaceae) is a gram-negative nonspore-forming, nonencapsulated, straight rod bacterium with peritrichous flagellae (Grimont et al., 1988). Pathogenic strains of S. entomophila infect their host by colonizing the larval gut and adhering to the crop; as a result starvation is induced causing the depletion of the fat bodies (Klein and Kaya, 1995). Consequently, this series of events ultimately causes the appearance of an amber color (Jackson et al., 1993), which gives its name to the disease (Klein and Kaya, 1995). It has been found that pathogenic strains of S. entomophila and $S$. proteamaculans causing amber disease contain a specific plasmid (Hurst et al., 2000). However, despite intensive testing, no other scarab species apart from Costelytra zealandica has been found susceptible to the plasmid-bearing strains (Jackson and Klein, 2006).

\section{Rickettsiella sp.}

Rickettsiella sp. is another bacterium that has been isolated from African black beetle and thus highlighted as a potential biological control agent for scarabs. Along with a protozoan, possibly Adelina sp., Rickettsia sp. was the most abundant pathogen isolated by Longworth and Archibald (1975). The genus Rickettsiella is made-up of intracellular bacterial pathogens of a wide range of arthropods (Leclerque et al., 2011). They are characterized by causing intracoelomic infections, multiplying in vacuolar structures within fat body cells and are often associated with protein crystals (Kleespies et al., 2011). However, infected larvae may live for several months (Longworth and Archibald, 1975).

\section{PROTOZOA}

Protozoan control agents offer persistence in host populations while decreasing overall fitness and reproduction of the target species, however, they produce low levels of immediate mortality (e.g., chronic infections) and in vivo production is required to prepare and release overwhelming amounts of the control agent (inundative application) (Lacey et al., 2001).

\section{VIRUS}

Isolations from diseased larvae and adults of African black beetle have revealed a number of pathogens, including a small isometric virus (30 $\mathrm{nm}$ in diameter) that develops in the cytoplasm of gut and fat-body cells (Longworth and Archibald, 1975). Longworth and Carey (1976) described this RNA virus as being icosahedral in shape without any obvious surface features. Moreover, it has a sedimentation coefficient of $137 \mathrm{~S}$, a buoyant density in $\mathrm{CsC} 1$ of $1.33 \mathrm{~g} / \mathrm{ml}$ and RNA:protein ratio of 28.2:71.8. The virus was found to be infective for numerous species in the Lepidoptera and Coleoptera orders and also for Drosophila melanogaster cells in tissue culture (Crump and Moore, 1981). However, the low infection rate of the virus on African black beetle observed by Longworth and Archibald (1975) in the field was not enough to explain the mortality observed in the population.

\section{FUNGI}

Entomopathogenic fungi of the genera Metarhizium and Beauveria are omnipresent in soils; however, infectivity in scarabs is limited to certain strains mostly of the species B. brongniarti and the large-spored M. anisopliae var. majus (Jackson and Klein, 2006). Beauveria sp. has been isolated from African black beetle larvae (Longworth and Archibald, 1975) and has been considered as a potential biological control agent. Zimmermann (2007) summarized the infection pathway of Beauveria sp. and other entomopathogenic fungi in a sequence of events: attachment of the spore to the cuticle, germination, penetration of the cuticle, overcoming the immune response of the host, proliferation, saprophytic outgrow from the carcass and production of new conidia. However, when considering entomopathogenic fungi as biological control agents for soil-dwelling species, the ability of the entomopathogen to persist for an extended period of time as well as its infectivity to the host must be taken into account (Lingg and Donaldson, 1981). The survival and proliferation of these fungi can be affected by a number of abiotic factors such as temperature, humidity or moisture and solar radiation (Zimmermann, 2007).

\section{CHEMICAL CONTROL}

Management of subterranean pest species such as African black beetle is challenging because of the high damage potential per individual, therefore the success of any control method(s) depends on the reduction of the population to the minimum (Bulinski and Matthiessen, 2002). Many of the pesticides previously used for African black beetle control have either been withdrawn from the market or are no longer registered for that purpose. Traditionally, persistent broad-spectrum organochlorine products were deployed with cultivation and incorporated into the soil in order to protect crops from African black beetle (Bulinski and Matthiessen, 2002). In recent years, targeted insecticides such as insect growth regulators and neonicotinoid compounds have been developed (Jackson and Klein, 2006). Imidacloprid (Merit, Bayer, Kansas City, MO, USA) and halofenozide (Mach 2, RohMid, Parsippany, NJ, USA) have become widely used for preventive control of root-feeding scarabaeid grubs (Kunkel et al., 2001). However, Kunkel et al. (1999) found that imidacloprid and halofenozide may have disruptive effects on earthworms and some predatory invertebrates, but such effects are short-lived and unlikely to 
cause pest outbreaks. In contrast, Prabhaker et al. (2011) found limited but detrimental effects of neonicotinoid compounds (imidacloprid and thiamethoxam) on some beneficial insects and maintained a more conservative approach, arguing that further investigation is required.

Imidacloprid and halofenozide are most effective against early larval instars (first and second instars), and must be applied before larval damage is visible (Jackson and Klein, 2006). However, third instar larvae are known to cause the most damage (Lacey et al., 2001). When evaluating spring and autumn applications of chlorpyrifos, alpha-cypermethrin, and diazinon for African black beetle control, Eden et al. (2011) concluded that the use of such pesticides is not recommended because of the difficulty in application timing, the inefficiency of treatments, and the likelihood that reinvasion will occur as these treatments do not prevent subsequent larval populations from causing damage.

\section{SEED TREATMENT}

It has been suggested that treated seeds (i.e., dressing, film coating, pelleting, or multilayer coating) present an environmentally safe method of protection for young plants against insect pests (Elbert et al., 2008). Seeds coated with insecticides (imidacloprid and furathiocarb) produce plants that are protected against stem borers (e.g., African black beetle) through systemic translocation of the insecticides (Drinkwater and Groenewald, 1994). However, Drinkwater (2003) found that in order to deter beetles, they have to feed on the plant first. Furthermore, a number of biological factors such as the age of the beetle influence the level of efficacy of the compound (Drinkwater, 2002). Drinkwater (2003) concluded all neonicotinoids evaluated significantly reduced insect damage to the host plant, but only imidacloprid reduced beetle abundance. Bell et al. (2011) suggested that treated seeds might play a crucial role in pasture establishment during outbreak years, as well as helping to control population numbers and avoid the risks of population build-up after pasture renewal.

\section{SILICON SUPPLEMENTATION}

Plant silicon is known to play a role in defense against pathogens and herbivores (Epstein, 2009). In grasses, silicon-based defenses provide a physical barrier that counters herbivores and pathogens (Massey et al., 2006; Massey and Hartley, 2009; Reynolds et al., 2009).

Massey and Hartley (2009) demonstrated that silica-rich diets increase mandible wear and decrease digestibility and absorption of nitrogen from food plants in African armyworm (Spodoptera exempta). In addition, silicon can also affect subterranean herbivores. Frew et al. (2016) found that silicon applications can play a significant role in defense against root-feeding pests such as greyback cane beetle larvae (Dermolepida albohirtum).

Silicon is the second most abundant element in soils (Epstein, 1994) but needs to be in the soluble form of monosilicic acid $\left[\mathrm{Si}(\mathrm{OH})_{4}\right]$ to be taken up by the plant roots (Guével et al., 2007). Once metabolized, silicon can provide a physical defense based on the mechanical properties of opaline silica (Garbuzov et al., 2011). Silicon concentrations within a grass species are not static but can increase when the plant is under herbivore attack (Massey et al., 2007), suggesting that there is a fitness cost associated with this defense (Garbuzov et al., 2011). It is thought that silicon defense fitness costs might place the plant at a disadvantage against its competitors in the absence of herbivores (Hanley and Sykes, 2009).

Silicon supplementation has shown promising results at deterring herbivores above and below ground (Massey and Hartley, 2009; Frew et al., 2016). It relies, however, on the availability of soluble silicon (Guével et al., 2007) and herbivore stimuli for plants to invest in this defense strategy (Massey et al., 2007). Silicon supplementation could complement other management strategies such as chemical defenses that can improve overall plant health and resistance (i.e., endophytes). However, it is important to take into account that silicon may reduce digestibility and grazing preference in vertebrates (e.g., sheep, Glenn et al., 1989).

\section{ENDOPHYTE AS A CONTROL METHOD}

Epichloë (syn. Neotyphodium) has been described in early publications as an endophytic fungus of grasses such as perennial ryegrass and tall fescue (Sampson, 1933). Although endophytes are inconspicuous in planta (Iannone et al., 2011), infected plants can experience increased growth, reproduction, and resistance to various biotic and abiotic stress factors (Clay and Schardl, 2002). Biotic resistance of endophyte-infected plants has been associated with an array of secondary metabolites (alkaloids) produced by the fungus that benefit the host plant as they provide resistance against herbivores and pathogens (Siegel et al., 1987; Wilson, 1993; Zain, 2011). Toxicosis in cattle and sheep has been associated with the ingestion of endophyte-infected pastures, decreasing animal performance, and in some cases causing death (Fletcher and Harvey, 1981; D’Mello and MacDonald, 1997). It has been determined that ergopeptine (ergovaline) alkaloids are responsible for causing tall fescue staggers or fescue toxicosis (Paterson et al., 1995), while isoprenoid lolitrem (lolitrem B) alkaloids are responsible for causing ryegrass staggers (Smith et al., 1997).

On the other hand, some alkaloids have proven to be beneficial, conferring insecticidal properties to the plant, such as the pyrrolopyrazine alkaloid peramine that acts as a feeding deterrent to the Argentine stem weevil (Rowan and Gaynor, 1986; Rowan, 1993) and epoxy-janthitrems (indole-diterpenes) which are produced by an endophyte variety called AR37 (Thom et al., 2014). Epoxy-janthitrems have been reported not to cause ryegrass staggers in cattle (Moate et al., 2012). In addition, loline has shown both feeding deterrence and insecticidal activity (Schardl et al., 2007), while only causing negative effects in mammals at extremely high concentrations (Strickland et al., 1994; Oliver et al., 1998).

When comparing livestock performance on endophyteinfected and endophyte-free swards, Prestidge et al. (1982) found that non-infected pasture was severely damaged by the Argentine 
stem weevil, highlighting the importance of the endophyte (Prestidge et al., 1982). Endophytes have been reported to offer protection against a number of insect pests, including black cutworm (Agrotis ipsilon) (Baldauf et al., 2011), pasture mealybug (Balanococcus poae) (Pennell et al., 2005), Argentine stem weevil (Prestidge and Gallagher, 1988b), root aphids (Popay and Thom, 2009), and Japanese beetle and other white grubs (Scarabaeidae spp.) (Potter et al., 1992) including African black beetle (Bell et al., 2011).

In a field trial comparing different grass treatments, African black beetle populations in perennial ryegrass pastures harboring AR37, AR1, and wild-type endophyte remained low and their mean densities in these treatments were significantly less than those pastures without endophyte (Thom et al., 2014). Therefore, considerable research has been done on the alkaloids produced by fungi because of the services they provide to their host plant and agricultural systems (Clay and Schardl, 2002).

It has been found that the level of chemicals produced by an endophyte in symbiosis with a plant varies depending on the endophyte-plant combination (Panka et al., 2013). This is particularly important as endophyte-infected grasses containing ergot alkaloids (ergovaline) that are known to have detrimental effects on cattle (Smith et al., 1997; Bell et al., 2011) can also deter important pests such as African black beetle (Ball et al., 1997b). Therefore, screening endophyte-plant combinations to find a balanced chemical profile that protects the plants from pests without affecting cattle would be beneficial. In order to achieve this, it is necessary to understand the chemistry behind these processes (i.e., active compounds, intermediate compounds, and possible synergistic effects).

Ball et al. (1997b) tested alkaloid toxicity on adult African black beetle by incorporating them in an artificial diet, and found that ergopeptine alkaloids significantly reduced feeding at concentration of $5 \mu \mathrm{g} / \mathrm{g}$, whereas ergopeptine epimer and its analogs were also active but to a lesser extent. In addition, he found that peramine, lolitrem B and a number of ergot alkaloids had no effect on deterring adult beetles, except for ergonovine which showed moderate activity.

As for insecticides (Jackson and Klein, 2006), the effects of endophyte infected grasses on African black beetle can vary depending on their different life stage. Previous studies have demonstrated that certain endophyte strains deter adult beetles from feeding (Ball et al., 1994), resulting in a decrease of survival and oviposition. However, commercially available endophyte strains do not seem to have negative effects on the larval form (Bell et al., 2011). Similarly, Watson (2006) found no evidence of alkaloids produced by endophyte-infected perennial ryegrass or tall fescue affecting redheaded cockchafer and black headed cockchafer larval stages. However, Bryant et al. (2010) found loline concentrations in excess of $1700 \mu \mathrm{g} / \mathrm{g}$ DM were particularly effective in reducing feeding and development of second instar redheaded cockchafer but not African black beetle larvae.

Endophytes have been screened to produce less toxic profiles to livestock, whilst maintaining other beneficial traits, such as the production of insect deterrent alkaloids (Johnson et al., 2013). In the case of vertebrates, it has been determined that some toxic alkaloids, such as ergot alkaloids, behave like neurotransmitters (i.e., dopamine, serotonin, and adrenaline) causing vasoconstriction, smooth muscle contraction, bewilderment, and hallucinations (Beaulieu et al., 2013). In addition, penitrem, paxilline, and lolitrem $B$ are also known to be tremorgenic and have been associated with diseases of domestic animals and mice (Gallagher et al., 1981; Smith et al., 1997). However, the exact mechanisms of action of how endophytes affect soil-borne herbivores are still to be determined (Malinowski and Belesky, 2000). In a bioassay conducted on Argentine stem weevil, Rowan (1993) found definite but minimal structural requirements for insect deterrence activity caused by peramine and its analogs. All analogs tested were less active than peramine itself, suggesting some importance for the guanidinium group and the side-chain in obtaining the full biological response. A better understanding of the mode of action of alkaloids on soil-borne insects might provide valuable information for the development of novel endophytes to control the more resistant life-stage (i.e., larval form).

Clay (1989) suggested that an efficient biological control agent is characterized by its capacity to significantly decrease pest damage either by directly killing or damaging the pest, reducing its population growth, or by deterring the pest before it can do any damage. Endophytes have shown to offer insect deterrent activity to their host plant against certain pests as well as inducing resistance in their host plant to various other biotic factors (Clay and Schardl, 2002).

Even though there are a number of pathogens associated with scarabs, it appears that many occur at low levels and scarabs appear to show inherent resistance to many generalist pathogens (Jackson and Klein, 2006). In contrast, endophytes as a control method have a clear advantage, as they are present within host-plant grasses (Iannone et al., 2011) and they are transmitted vertically through seeds (Schardl, 1996). Therefore, in terms of presence, endophytes can be expressed in paddocks offering continued protection to their host plant. In addition, the chemical profile produced by an endophyte, in symbiosis with a plant, varies depending on the endophyte-plant combination (Panka et al., 2013) and as a result, endophyte-plant combinations could be selected according their chemical profile and the target pest affecting the plant.

Wild-type endophyte-infected grasses which contain lolitrem $B$ and ergovaline offer insect control, but consumption by dairy cows may result in ryegrass staggers, reduction in feed intake, and losses in milk production (Thom et al., 2014). In recent years, development efforts have focused upon endophyte-grass host associations that produce little or no ergot alkaloids toxic to livestock yet still maintain pest resistance qualities of the more toxic profiles (Malinowski and Belesky, 2000).

Bell et al. (2011), however, states that endophytes could face limitations during African black beetle outbreaks, as insectdeterrence conferred by the best selected endophytes may not be sufficient to prevent larvae population build up or new infestations arising as a result of flight dispersal by adult beetles in late autumn or spring. Furthermore, Jackson and Klein (2006) concluded that while chemical control will be still used as a quick fix for scarab problems, integrated pest management (IPM) offers a better long-term solution. Integrated pest management 
(IPM) refers to the synergistic use of multiple control strategies (e.g., cultural, chemical, and biological) based on surveillance information to assess and control pests in an ecologically and economically sound manner (All, 2005; Ehler, 2006). Kauppinen et al. (2016) proposed that Epichloë endophytes should be considered when developing sustainable management strategies for agriculture, as endophyte-infected grasses could be used as alternatives and/or in conjunction with synthetic plant protection products.

In view of the above, the use of endophytes may aid to control insect pest populations and therefore reduce the need for pesticide applications in the field. Prabhaker et al. (2011) argues that even though neonicotinoid compounds (imidacloprid and thiamethoxam) used for soil-borne insects are generally assumed to be safe they can have negative effects on beneficial insects (e.g., via food chain toxicity; following feeding on plant tissue or excretions) if they are exposed to the pesticide.

Consequently, the use of endophytes might allow the recruitment of natural predators which have been suggested to play a key role in the prevention of pest outbreaks in sustainable agricultural systems (Kromp, 1999). Riechert (1999) argues that the presence of natural predators can affect pest species by deterring pests, causing them to utilize unsuitable areas that are less productive, or even cease feeding completely; ultimately, delaying the outbreak phase by controlling population numbers when they are below plague levels.

Endophytes may play a crucial role in IPM in sustainable agricultural systems, as they not only enhance host plant resistance to biotic factors but also to abiotic factors (Clay and Schardl, 2002). Some examples of IPM approaches for scarab control include the combination of entomopathogenic nematodes Heterorhabditis megidis and Steinernema glaseri with Metarhizium anisopliae (Ansari et al., 2004) and also the combination of imidacloprid with entomopathogenic nematodes (Koppenhöfer et al., 2000). However, the combination of two different control strategies does not necessarily result in the desired outcome. Walston et al. (2001) found a lack of synergism

\section{REFERENCES}

ABARES (2014). Agricultural Commodities September Quarter 2014. Canberra, ACT: Australian Bureau of Agricultural and Resource Economics and Sciences. Abbott, I. (1993). Insect pest problems of eucalypt plantations in Australia. Aust. For. 56, 381-384. doi: 10.1080/00049158.1993.10674631

Adler, P., Raff, D., and Lauenroth, W. (2001). The effect of grazing on the spatial heterogeneity of vegetation. Oecologia 128, 465-479. doi: $10.1007 /$ s004420100737

Alexander, G., and Williams, O. B. (1973). The Pastoral Industries of Australia: Practice and Technology of Sheep and Cattle Production. Portland: Sydney University Press [distributed in the U.S. by International Scholarly Book Services, Incorporated].

All, J. (2005). Integrated Pest Management (IPM). Encyclopedia of Entomology. Dordrecht: Springer.

Allsopp, P. G. (1995). Biogeography of the Australian Dynastinae, Rutelinae, Scarabaeinae, Melolonthini, Scitalini and Geotrupidae (Coleoptera: Scarabaeoidea). J. Biogeogr. 22, 31-48. doi: 10.2307/2846071

Altieri, M. A. (1999). The ecological role of biodiversity in agroecosystems. Agric. Ecosyst. Environ. 74, 19-31. doi: 10.1016/S0167-8809(99)00028-6 between endophyte infected perennial ryegrass and $P$. popilliae on Japanese Beetle. Perhaps a combination of chemical agents, such as targeted pesticides (e.g., imidacloprid) applied as seed treatments plus the application of soluble silica could help establish endophyte-infected grass when renewing pastures, and supplement entomopathogenic nematodes and other natural predators in an IPM strategy.

To conclude this literature review it is apparent that African black beetle is not a pest that can be controlled with a single strategy and requires a more holistic approach. The design of an IPM program that works on-farm is necessary. To achieve this, different methods of control that are synergistic should be aligned with farmers needs and capabilities. Based on the advantages described in this review, selection of an ideal endophyte-grass combination could be a first step to develop such an IPM program.

\section{AUTHOR CONTRIBUTIONS}

MK: researched the relevant literature and wrote the body of the article. AY: contributed with information regarding insects and ecology, as well as, editing the article. SR: contributed mainly in the biochemistry part of the article, information about secondary metabolites, as well as, editing the article. KG: contributed with information about ryegrass endophyte, as well as, editing the article. KP: edited the final version of the article. JE: edited the final version of the article. GS: provided overall direction for the program of work.

\section{ACKNOWLEDGMENTS}

This work was supported by the Victorian Department of Economic Development, Jobs, Transport and Resource and the Dairy Futures Cooperative Research Centre. This paper is part of a $\mathrm{PhD}$ project and it was written based on the relevant literature for this project. Special thanks to Annette Peisley for contributing information about Australian history.

Altieri, M. A., Letourneau, D. K., and Risch, S. J. (1984). Vegetation diversity and insect pest outbreaks. Crit. Rev. Plant Sci. 2, 131-169. doi: 10.1080/07352688409382193

Andow, D. A. (1991). Vegetational diversity and arthropod population response. Annu. Rev. Entomol. 36, 561-586. doi: 10.1146/annurev.en.36.010191.003021

Ansari, M. A., Tirry, L., and Moens, M. (2004). Interaction between Metarhizium anisopliae CLO 53 and entomopathogenic nematodes for the control of Hoplia philanthus. Biol. Control 31, 172-180. doi: 10.1016/j.biocontrol.2004.04.002

Arpaia, S., De Marzo, L., Di Leo, G. M., Santoro, M. E., Mennella, G., and Van Loon, J. J. A. (2000). Feeding behaviour and reproductive biology of Colorado potato beetle adults fed transgenic potatoes expressing the Bacillus thuringiensis Cry3B endotoxin. Entomol. Exp. Appl. 95, 31-37. doi: 10.1046/j.1570-7458.2000.00638.x

Arpaia, S., Di Leo, G. M., Fiore, M. C., Schmidt, J. E., and Scardi, M. (2007). Composition of arthropod species assemblages in Bt-expressing and near isogenic eggplants in experimental fields. Environ. Entomol. 36, 213-227. doi: 10.1603/0046-225X(2007)36[213:COASAI]2.0.CO;2

Bacon, C. W. (1993). Abiotic stress tolerances (moisture, nutrients) and photosynthesis in endophyte-infected tall fescue. Agric. Ecosyst. Environ. 44, 123-141. doi: 10.1016/0167-8809(93)90042-N 
Bailey, P. T. (2007). Pests of Field Crops and Pastures: Identification and Control. Collingwood, ON: CSIRO Publishing.

Baldauf, M. W., Mace, W. J., and Richmond, D. S. (2011). Endophyte-mediated resistance to black cutworm as a function of plant cultivar and endophyte strain in tall fescue. Environ. Entomol. 40, 639-647. doi: 10.1603/EN09227

Balfourier, F., Imbert, C., and Charmet, G. (2000). Evidence for phylogeographic structure in Lolium species related to the spread of agriculture in Europe. A cpDNA study. Theor. Appl. Genet. 101, 131-138. doi: 10.1007/s001220051461

Ball, O. J. P., Barker, G. M., Prestidge, R. A., and Lauren, D. R. (1997a). Distribution and accumulation of the alkaloid peramine in Neotyphodium lolii-infected perennial ryegrass. J. Chem. Ecol. 23, 1419-1434. doi: 10.1023/B:JOEC.0000006473.26175.19

Ball, O. J.-P., Christensen, M. J., Prestidge, R. A., and Popay, A. J. (1994). "Effect of selected isolates of Acremonium endophyte on adult black beetle (Heteronychus arator) feeding," in Proceedings of the 47th New Zealand Plant Protection Conference (Waitangi), 227-231.

Ball, O. J. P., Miles, C. O., and Prestidge, R. A. (1997b). Ergopeptine alkaloids and Neotyphodium lolii-mediated resistance in perennial ryegrass against adult heteronychus arator (Coleoptera: Scarabaeidae). J. Econ. Entomol. 90, 1382-1391. doi: 10.1093/jee/90.5.1382

Batley, M., and Hogendoorn, K. (2009). Diversity and conservation status of native Australian bees. Apidologie 40, 347-354. doi: 10.1051/apido/2009018

Beard, R. L. (1956). Two milky diseases of australian scarabaeidae. Can. Entomol. 88, 640-647. doi: 10.4039/Ent88640-11

Beaulieu, W. T., Panaccione, D. G., Hazekamp, C. S., Mckee, M. C., Ryan, K. L., and Clay, K. (2013). Differential allocation of seed-borne ergot alkaloids during early ontogeny of morning glories (Convolvulaceae). J. Chem. Ecol. 39, 919-930. doi: 10.1007/s10886-013-0314-z

Beilharz, R. G., and Halloran, G. M. (1987). "Biological resources. 53-72," in Cunningham, P. J., Blumenthal, M. J., Anderson, M. W., Prakash, K. S. and Leonforte, A. (1994). Perennial ryegrass improvement in Australia. New Zealand J. Agric. Res. 37, 295-310. doi: 10.1080/00288233.1994.9513068

Bell, N., Townsend, R., Popay, A., Mercer, C., and Jackson, T. (2011). "Black beetle: lessons from the past and options for the future," in New Zealand Grassland Association Pasture Persistence Symposium. Grassland Research and Practice Series, 119-124.

Bennett, A. F., Lumsden, L. F., and Nicholls, A. O. (1994). Tree hollows as a resource for wildlife in remnant woodlands: spatial and temporal patterns across the Northern Plains of Victoria, Australia. Pac. Conserv. Biol. 1, 222-235. doi: 10.1071/PC940222

Berg, G., Faithfull, I. G., Powell, K. S., Bruce, R. J., Williams, D. G., and Yen, A. L. (2014). Biology and management of the redheaded pasture cockchafer Adoryphorus couloni (Burmeister) (Scarabaeidae: Dynastinae) in Australia: a review of current knowledge. Aust. Entomol. 53, 144-158. doi: 10.1111/aen.12062

Billis, R. V., Kenyon, A. S., and Cotton, J. (1930). Pastures New: An Account of the Pastoral Occupation of Port Phillip. Melbourne, VIC: Macmillan Limited.

Blank, R. H., and Olson, M. H. (1988). Effect of black beetle, in association with nitrogen and summer spelling, on pasture production on sandy soils. N.Z. J. Agric. Res. 31, 445-453. doi: 10.1080/00288233.1988.10423440

Bryant, R. H., Cameron, N. E., and Edwards, G. R. (2010). Response of black beetle and red-headed pasture cockchafer larvae to loline alkaloids in meadow fescue roots. N.Z. Plant Prot. 63, 219-223.

Bulinski, J., and Matthiessen, J. N. (2002). Poor efficacy of the insecticide chlorpyrifos for the control of African black beetle (Heteronychus arator) in eucalypt plantations. Crop Prot. 21, 621-627. doi: 10.1016/S0261-2194(02)00012-1

Bulinski, J., Matthiessen, J. N., and Alexander, R. (2006). Development of a cost-effective, pesticide-free approach to managing African black beetle (Heteronychus arator) in Australian eucalyptus plantations. Crop Prot. 25, 1161-1166. doi: 10.1016/j.cropro.2005.12.006

Burnell, A. M., and Stock, S. P. (2000). Heterorhabditis, Steinernema and their bacterial symbionts - Lethal pathogens of insects. Nematology 2, 31-42. doi: $10.1163 / 156854100508872$

Cameron,. P. J., Valentine, E. W., and Butcher, C. F. (1979). "Prospects for biological control of pasture Scarabaeidae (Coleoptera) in New Zealand," in Proceedings of the 2nd Australasian Conference on Grassland Invertebrate Ecology, (Palmerston North), 213-216.
Carrick, R. (1959). The food and feeding habits of the Straw-necked Ibis, Threskiornis spinicollis (Jameson), and the White Ibis, T. molucca (Cuvier) in Australia. CSIRO Wildlife Res. 4, 69-92. doi: 10.1071/CWR9590069

Chambers, J. A., Jelen, A., Gilbert, M. P., Jany, C. S., Johnson, T. B., and Gawron-Burke, C. (1991). Isolation and characterization of a novel insecticidal crystal protein gene from Bacillus thuringiensis subsp. aizawai. J. Bacteriol. 173, 3966-3976. doi: 10.1128/jb.173.13.3966-3976.1991

Chapman, D. F., Kenny, S. N., Beca, D., and Johnson, I. R. (2008). Pasture and forage crop systems for non-irrigated dairy farms in southern Australia. 1. Physical production and economic performance. Agric. Syst. 97, 108-125. doi: 10.1016/j.agsy.2008.02.001

Christensen, M. J., Bennett, R. J., and Schmid, J. (2002). Growth of Epichlo\&euml;/Neotyphodium and p-endophytes in leaves of Lolium and Festuca grasses. Mycol. Res. 106, 93-106. doi: 10.1017/S095375620100510X

Christensen, M. J., Leuchtmann, A., Rowan, D. D., and Tapper, B. A. (1993). Taxonomy of Acremonium endophytes of tall fescue (Festuca arundinacea), meadow fescue (F. pratensis) and perennial ryegrass (Lolium perenne). Mycol. Res. 97, 1083-1092. doi: 10.1016/S0953-7562(09)80509-1

Cidaria, D., Cappai, A., Vallesi, A., Caprioli, V., and Pirali, G. (1991). A novel strain of Bacillus thuringiensis (NCIMB 40152) active against coleopteran insects. FEMS Microbiol. Lett. 81, 129-133. doi: 10.1111/j.1574-6968.1991.tb04734.x

CIE (2011). The Impact of Innovation on the Dairy Industry Over the Last 30 Years: Evaluating the Contribution of Industry and Government Investment in Pre Farm Gate RD\&E, a Report Prepared for Dairy Australia and the Victorian Department of Primary Industries. Available online at: http:// www.dairyaustralia.com.au/Industry-overview/About-Dairy-Australia/ Publications-2/ /media/82E156D1B32C4C86982C3E8876A07057.ashx (Accessed August 25, 2016).

Clark, C. M. H. (1962). A History of Australia: From the Earliest Times to the Age of Macquarie. Melbourne, VIC: Melbourne University Press.

Clark, S. G., Nie, Z. N., Culvenor, R. A., Harris, C. A., Hayes, R. C., Li, G. D., et al. (2016). Field evaluation of cocksfoot, tall fescue and phalaris for dry marginal environments of South-Eastern Australia. 1. Establishment and herbage production. J. Agron. Crop Sci. 202, 96-114. doi: 10.1111/jac.12152

Clay, K. (1989). Clavicipitaceous endophytes of grasses: their potential as biocontrol agents. Mycol. Res. 92, 1-12. doi: 10.1016/S0953-7562(89)80088-7

Clay, K., and Schardl, C. L. (2002). Evolutionary origins and ecological consequences of endophyte symbiosis with grasses. Am. Nat. 160, S99-S127. doi: $10.1086 / 342161$

Collins, K. L., Boatman, N. D., Wilcox, A., Holland, J. M., and Chaney, K. (2002). Influence of beetle banks on cereal aphid predation in winter wheat. Agric. Ecosyst. Environ. 93, 337-350. doi: 10.1016/S0167-8809(01)00340-1

Coman, B. (1973). The diet of red foxes, Vulpes vulpes L., in Victoria. Aust. J. Zool. 21, 391-401. doi: 10.1071/ZO9730391

Conant, R. T., Paustian, K., and Elliott, E. T. (2001). Grassland management and conversion into grassland: effects on soil carbon. Ecol. Appl. 11, 343-355.

Cook, G. D., and Dias, L. (2006). Turner Review No. 12. It was no accident: deliberate plant introductions by Australian government agencies during the 20th century. Aust. J. Bot. 54, 601-625. doi: 10.1071/BT05157

Coxen, C. (1866). The Kommillaroy tribe. Trans. Philos. Soc. Queensl. 1, 1-4.

Crawford, K. M., Land, J. M., and Rudgers, J. A. (2010). Fungal endophytes of native grasses decrease insect herbivore preference and performance. Oecologia 164, 431-444. doi: 10.1007/s00442-010-1685-2

Crump, W. A. L., and Moore, N. F. (1981). The polypeptides induced in drosophila cells by a virus of Heteronychus arator. J. Gen. Virol. 52, 173-176. doi: 10.1099/0022-1317-52-1-173

Cumpston, D. (1940). "On the external morphology and biology of Heteronychus sanctae-Helenae Blanch. and Metanastes vulgivagus Olliff (Col., Scarabaeidae, Dynastinae)," in Proceedings of the Linnaean Society of New South Wales, 289-300.

Cunningham, P. J., Blumenthal, M. J., Anderson, M. W., Prakash, K. S., and Leonforte, A. (1994). Perennial ryegrass improvement in Australia. N.Z. J. Agric. Res. 37, 295-310. doi: 10.1080/00288233.1994.9513068

Cunningham, P. J., Graves, W. L., Chakroun, M., Mezni, M. Y., Saidi, S., Bounejmate, M., et al. (1997). Novel perennial forage germplasm from North Africa and Sardinia. Aust. Plant Introduc. Rev. 27, 13-46.

Deml, R., Meise, T., and Dettner, K. (1999). Effects of Bacillus thuringiensis $\delta \delta$ endotoxins on food utilization, growth, and survival of selected phytophagous 
insects. J. Appl. Entomol. 123, 55-64. doi: 10.1046/j.1439-0418.1999. 00312.x

Denettancourt, D. (1977). Incompatibility in angiosperms. New York, NY: Springer Verlag.

Dingman, D. W. (1994). Inhibitory effects of turf pesticides on Bacillus popilliae and the prevalence of milky disease. Appl. Environ. Microbiol. 60, 2343-2349.

D'Mello, J. P. F., and MacDonald, A. M. C. (1997). Mycotoxins. Anim. Feed Sci. Technol. 69, 155-166. doi: 10.1016/S0377-8401(97)81630-6

Dorrough, J., Yen, A., Turner, V., Clark, S. G., Crosthwaite, J., and Hirth, J. R. (2004). Livestock grazing management and biodiversity conservation in Australian temperate grassy landscapes. Aust. J. Agric. Res. 55, 279-295. doi: 10.1071/AR03024

Douglas, M. H. (1972). Red-headed cockchafer can be controlled by pasture management. J. Agric. 70, 61-63.

Drane, N. T., and Edwards, H. R. (1961). The Australian Dairy Industry: An Economic Study. Melbourne, VIC: F. W. Cheshire.

Drinkwater, T. (2002). Effect of application rate and beetle age on efficacy of imidacloprid (Gaucho $($ ) ) against black maize beetle, Heteronychus arator Fabricius (Coleoptera: Scarabaeidae). S.Afr. J. Plant Soil 19, 99-103. doi: 10.1080/02571862.2002.10634446

Drinkwater, T. W. (1979). "Maize production: the black maize beetle," Farming in South Africa. Maize Series D. Insects and related pests, Leaflet D.4, 1-4.

Drinkwater, T. W. (2003). Bioassays to compare the systemic activity of three neonicotinoids for control of Heteronychus arator Fabricius (Coleoptera: Scarabaeidae) in maize. Crop Prot. 22, 989-993. doi: 10.1016/S0261-2194(03)00116-9

Drinkwater, T. W., and Groenewald, L. H. (1994). Comparison of imidacloprid and furathiocarb seed dressing insecticides for the control of the black maize beetle, Heteronychus arator Fabricius (Coleoptera: Scarabaeidae), in maize. Crop Prot. 13, 421-424. doi: 10.1016/0261-2194(94)90088-4

Dutky, S. (1940). Two new spore-forming bacteria causing milky diseases of Japanese beetle larvae. J. Agric. Res. 61, 57-68.

East, R., King, P. D., and Watson, R. N. (1981). Population studies of grass grub (Costelytra zealandica) and black beetle (Heteronychus arator) (Coleoptera: Scarabaeidae). N.Z. J. Ecol. 4, 56-64.

East, R., and Pottinger, R. P. (1975). Starling (Sturnus vulgaris L.) predation on grass grub (Costelytra zealandica (White), Melolonthinae) populations in Canterbury. N.Z. J. Agric. Res. 18, 417-452.

Easton, H. S., Christensen, M. J., Eerens, J. P. J., Fletcher, L. R., Hume, D. E., Keogh, R. G., et al. (2001). Ryegrass endophyte: a New Zealand Grassland success story. Proc. N.Z. Grassland Assoc. 63, 37-46.

Eden, T. M., Gerard, P. J., Wilson, D. J., and Addison, P. J. (2011). Evaluation of spring and autumn applied insecticides for the control of black beetle. N.Z. Plant Prot. 64, 63-67.

Ehler, L. E. (2006). Integrated pest management (IPM): definition, historical development and implementation, and the other IPM. Pest Manag. Sci. 62, 787-789. doi: 10.1002/ps.1247

Elbert, A., Haas, M., Springer, B., Thielert, W., and Nauen, R. (2008). Applied aspects of neonicotinoid uses in crop protection. Pest Manag. Sci. 64, 1099-1105. doi: 10.1002/ps.1616

Emden, H. F. V., and Williams, G. F. (1974). Insect stability and diversity in agro-ecosystems. Annu. Rev. Entomol. 19, 455-475. doi: 10.1146/annurev.en.19.010174.002323

Epstein, E. (1994). The anomaly of silicon in plant biology. Proc. Natl. Acad. Sci. 91, 11-17. doi: 10.1073/pnas.91.1.11

Epstein, E. (2009). Silicon: its manifold roles in plants. Ann. Appl. Biol. 155, $155-160$.

Erasmus, A., and Berg, J. V. D. (2014). Effect of Bt-Maize Expressing Cry1Ab Toxin on Non-Target Coleoptera and Lepidoptera Pests of maize in South Africa. Afr. Entomol. 22, 167-179. doi: 10.4001/003.022.0110

Fensham, R. J. (1998). The grassy vegetation of the darling downs, south-eastern Queensland, Australia. Floristics and grazing effects. Biol. Conserv. 84, 301-310. doi: 10.1016/S0006-3207(97)00105-5

Fiedler, A. K., Landis, D. A., and Wratten, S. D. (2008). Maximizing ecosystem services from conservation biological control: the role of habitat management. Biol. Control 45, 254-271. doi: 10.1016/j.biocontrol.2007. 12.009
Finneran, E., Crosson, P., O'kiely, P., Shalloo, L., Forristal, P. D., and Wallace, M. (2012). Economic modelling of an integrated grazed and conserved perennial ryegrass forage production system. Grass Forage Sci. 67, 162-176. doi: 10.1111/j.1365-2494.2011.00832.x

Fletcher, L. R., and Harvey, I. C. (1981). An association of a lolium endophyte with ryegrass staggers. N.Z. Vet. J. 29, 185-186. doi: 10.1080/00480169.1981.34839

Ford, P., Olszewski, I., and Nickson, D. (2001). Biological Control of African Black Beetle (Heteronychus arator) in Turf Using Entomopathogenic Nematodes [Online]. Victorian Golf Course Superintendents Association. Available online at: http://www.vgcsa.com.au/library/documents/Item\%2017.\%20african \%20black\%20beetle.pdf (Accessed 2015)

Frame, J. (1989). Herbage productivity of a range of grass species under a silage cutting regime with high fertilizer nitrogen application. Grass Forage Sci. 44, 267-276. doi: 10.1111/j.1365-2494.1989.tb02164.x

Frew, A., Nielsen, U. N., Riegler, M., and Johnson, S. N. (2013). Do eucalypt plantation management practices create understory reservoirs of scarab beetle pests in the soil? For. Ecol. Manag. 306, 275-280. doi: 10.1016/j.foreco.2013.06.051

Frew, A., Powell, J. R., Allsopp, P. G., Sallam, N., and Johnson, S. N. (2016). "Siliceous saviour of sugarcane: silicon alleviates negative impacts of belowground herbivory under elevated atmospheric CO2," in Invertebrate Ecology in Australasian Grasslands, Proceedings of the Ninth ACGIE, Vol. 7, ed S. N. Johnson (Hawkesbury, NSW: Western Sydney University).

Fuchs, B., Krischke, M., Mueller, M. J., and Krauss, J. (2013). Peramine and lolitrem B from endophyte-grass associations cascade up the food chain. J. Chem. Ecol. 39, 1385-1389. doi: 10.1007/s10886-013-0364-2

Funk, C. R., and White, J. Jr. (1997). "Use of natural and transformed endophytes for turf improvement," in Neotyphodium/Grass Interactions, Chapter 40, eds C. Bacon and N. Hill (New Brunswick, NJ: Springer), 229-239.

Gallagher, R. T., White, E. P., and Mortimer, P. H. (1981). Ryegrass staggers: isolation of potent neurotoxins lolitrem a and lolitrem B from staggersproducing pastures. N.Z. Vet. J. 29, 189-190. doi: 10.1080/00480169.1981. 34843

Garbuzov, M., Reidinger, S., and Hartley, S. E. (2011). Interactive effects of plantavailable soil silicon and herbivory on competition between two grass species. Ann. Bot. 108, 1355-1363. doi: 10.1093/aob/mcr230

Georgis, R., and Gaugler, R. (1991). Predictability in biological control using entomopathogenic nematodes. J. Econ. Entomol. 84, 73-720. doi: $10.1093 /$ jee/ 84.3 .713

Georgis, R., Koppenhöfer, A. M., Lacey, L. A., Bélair, G., Duncan, L. W., Grewal, P. S., et al. (2006). Successes and failures in the use of parasitic nematodes for pest control. Biol. Control 38, 103-123. doi: 10.1016/j.biocontrol.2005.11.005

Glenn, A. E., Bacon, C. W., Price, R., and Hanlin, R. (1996). Molecular phylogeny of Acremonium and its taxonomic implications. Mycologia 88, 369-383. doi: $10.2307 / 3760878$

Glenn, E. S., Mayland, H. F., Rosenau, R. C., and Asay, K. H. (1989). Silicon in C-3 grasses: effects on forage quality and sheep preference. J. Range Manag. 42, 122-127. doi: 10.2307/3899308

Goodman, D. (1975). The theory of diversity-stability relationships in ecology. Q. Rev. Biol. 50, 237-266. doi: 10.1086/408563

Gore, J., Adamczyk, J. J. Jr., and Blanco, C. A. (2005). Selective feeding of tobacco budworm and bollworm (Lepidoptera: Noctuidae) on meridic diet with different concentrations of Bacillus thuringiensis proteins. J. Econ. Entomol. 98, 88-94. doi: 10.1093/jee/98.1.88

Gott, B. (2005). Aboriginal fire management in south-eastern Australia: aims and frequency. J. Biogeogr. 32, 1203-1208. doi: 10.1111/j.1365-2699.2004.01233.x

Grimont, P. A. D., Jackson, T. A., Ageron, E., and Noonan, M. J. (1988). Serratia entomophila sp. nov. Associated with amber disease in the New Zealand grass grub Costelytra zealandica. Int. J. Syst. Bacteriol. 38, 1-6. doi: 10.1099/00207713-38-1-1

Groves, R. H., Austin, M. P., and Kaye, P. E. (2003). Competition between Australian native and introduced grasses along a nutrient gradient. Aust. Ecol. 28, 491-498. doi: 10.1046/j.1442-9993.2003.01305.x

Guével, M. H., Menzies, J. G., and Bélanger, R. R. (2007). Effect of root and foliar applications of soluble silicon on powdery mildew control and growth of wheat plants. Eur. J. Plant Pathol. 119, 429-436. doi: 10.1007/s10658-007-9181-1

Haider, M. Z., Knowles, B. H., and Ellar, D. J. (1986). Specificity of Bacillus thuringiensis var. colmeri insecticidal $\delta$-endotoxin is determined by differential 
proteolytic processing of the protoxin by larval gut proteases. Eur. J. Biochem. 156, 531-540. doi: 10.1111/j.1432-1033.1986.tb09612.x

Han, Y., Chen, J., Wang, H., Zhao, J., He, Y., and Hua, H. (2015). Preymediated effects of transgenic cry2Aa rice on the spider Hylyphantes graminicola, a generalist predator of Nilapavarta lugens. BioControl 60, 251-261. doi: 10.1007/s10526-014-9629-0

Hanley, M. E., and Sykes, R. J. (2009). Impacts of seedling herbivory on plant competition and implications for species coexistence. Ann. Bot. 103, 1347-1353. doi: 10.1093/aob/mcp081

Harrison, H., Patel, R., and Yousten, A. A. (2000). Paenibacillus associated with milky disease in Central and South American scarabs. J. Invertebr. Pathol. 76, 169-175. doi: 10.1006/jipa.2000.4969

Head, G., Surber, J. B., Watson, J. A., Martin, J. W., and Duan, J. J. (2002). No Detection of CrylAc Protein in Soil After Multiple Years of Transgenic Bt Cotton (Bollgard) Use. Environ. Entomol. 31, 30-36. doi: 10.1603/0046-225X-31.1.30

Hill, D. (2008). 1788: The Brutal Truth of the First Fleet: The Biggest Single Migration the World had Ever Seen. North Sydney, NSW: William Heinemann.

Hoffmann, A. A., Weeks, A. R., Nash, M. A., Mangano, G. P., and Umina, P. A. (2008). The changing status of invertebrate pests and the future of pest management in the Australian grains industry. Anim. Prod. Sci. 48, 1481-1493. doi: 10.1071/EA08185

Horne, P., and Page, J. (2008). Integrated Pest Management for Crops and Pastures. Collingwood, ON: Landlinks Press.

Humphreys, M. W., Yadav, R. S., Cairns, A. J., Turner, L. B., Humphreys, J., and Skøt, L. (2006). A changing climate for grassland research. New Phytol. 169, 9-26. doi: 10.1111/j.1469-8137.2005.01549.x

Hurst, M. R. H., Glare, T. R., Jackson, T. A., and Ronson, C. W. (2000). Plasmid-located pathogenicity determinants of Serratia entomophila, the causal agent of amber disease of grass grub, show similarity to the insecticidal toxins of Photorhabdus luminescens. J. Bacteriol. 182, 5127-5138. doi: 10.1128/JB.182.18.5127-5138.2000

Husband, B. C., and Schemske, D. W. (1996). Evolution of the magnitude and timing of inbreeding depression in plants. Evolution 50, 54-70. doi: $10.2307 / 2410780$

Iannone, L., White, J. Jr., Giussani, L., Cabral, D., and Victoria Novas, M. (2011). Diversity and distribution of Neotyphodium-infected grasses in Argentina. Mycol. Prog. 10, 9-19. doi: 10.1007/s11557-010-0669-2

Jackson, T. A., Huger, A. M., and Glare, T. R. (1993). Pathology of amber disease in the New Zealand grass grub Costelytra zealandica (Coleoptera: Scarabaeidae). J. Invertebr. Pathol. 61, 123-130. doi: 10.1006/jipa.1993.1024

Jackson, T. A., and Klein, M. G. (2006). Scarabs as pests: a continuing problem. Coleopt. Bull. 60, 102-119. doi: 10.1649/0010-065X(2006)60[102:SAPACP ]2.0.CO;2

Jacobs, J. L. (2014). Challenges in ration formulation in pasture-based milk production systems. Anim. Prod. Sci. 54, 1130-1140. doi: 10.1071/an14463

Jensen, C. S., Salchert, K., and Nielsen, K. K. (2001). A terminal flower1like gene from perennial ryegrass involved in floral transition and axillary meristem identity. Plant Physiol. 125, 1517-1528. doi: 10.1104/pp.125. 3.1517

Johns, C. V., Stone, C., and Hughes, L. (2004). Feeding preferences of the Christmas beetle Anoplognathus chloropyrus (Coleoptera: Scarabaeidae) and four paropsine species (Coleoptera: Chrysomelidae) on selected Eucalyptus grandis clonal foliage. Aust. For. 67, 184-190. doi: 10.1080/00049158.2004.10674932

Johnson, L. J., De Bonth, A. C. M., Briggs, L. R., Caradus, J. R., Finch, S. C., Fleetwood, D. J., et al. (2013). The exploitation of epichloae endophytes for agricultural benefit. Fungal Divers. 60, 171-188. doi: 10.1007/s13225-013-0239-4

Jouquet, P., Dauber, J., Lagerlöf, J., Lavelle, P., and Lepage, M. (2006). Soil invertebrates as ecosystem engineers: intended and accidental effects on soil and feedback loops. Appl. Soil Ecol. 32, 153-164. doi: 10.1016/j.apsoil.2005.07.004

Kati, H., Sezen, K., and Demirbağ, Z. (2007). Characterization of a highly pathogenicBacillus thuringiensis strain isolated from common cockchafer, Melolontha melolontha. Folia Microbiol. 52, 146-152. doi: 10.1007/BF02932153
Kauppinen, M., Saikkonen, K., Helander, M., Pirttil,ä, A. M., and Wäli, P. R. (2016). Epichloë grass endophytes in sustainable agriculture. Nat. Plants 2, 15224. doi: 10.1038/nplants.2015.224

King, K. L., Greenslade, P., and Hutchinson, K. J. (1985). Collembolan associations in natural versus improved pastures of the New England Tableland, NSW: distribution of native and introduced species. Aust. J. Ecol. 10, 421-427. doi: 10.1111/j.1442-9993.1985.tb00903.x

King, K. L., and Hutchinson, K. J. (1983). The effects of sheep grazing on invertebrate numbers and biomass in unfertilized natural pastures of the New England Tablelands (NSW). Aust. J. Ecol. 8, 245-255. doi: 10.1111/j.1442-9993.1983.tb01322.x

King, P. D., Mercer, C. F., and Meekings, J. S. (1981). Ecology of black beetle, Heteronychus arator (Coleoptera: Scarabaeidae) - influence of pasture species on oviposition site preference. N.Z. J. Zool. 8, 119-122. doi: 10.1080/03014223.1981.10427949

Kingston-Smith, A. H., Marshall, A. H., and Moorby, J. M. (2013). Breeding for genetic improvement of forage plants in relation to increasing animal production with reduced environmental footprint. Animal 7, 79-88. doi: $10.1017 /$ S1751731112000961

Kleespies, R. G., Marshall, S. D., Schuster, C., Townsend, R. J., Jackson, T. A., and Leclerque, A. (2011). Genetic and electron-microscopic characterization of Rickettsiella bacteria from the manuka beetle, Pyronota setosa (Coleoptera: Scarabaeidae). J. Invertebr. Pathol. 107, 206-211. doi: 10.1016/j.jip.2011. 05.017

Klein, M. G., and Kaya, H. (1995). Bacillus and Serratia species for scarab control. Mem. Inst. Oswaldo Cruz 90, 87-95. doi: 10.1590/S0074-02761995000100019

Koppenhöfer, A. M., Grewal, P. S., and Kaya, H. K. (2000). Synergism of imidacloprid and entomopathogenic nematodes against white grubs: the mechanism. Entomol. Exp. Appl. 94, 283-293. doi: 10.1046/j.1570-7458.2000.00630.x

Kromp, B. (1999). Carabid beetles in sustainable agriculture: a review on pest control efficacy, cultivation impacts and enhancement. Agric. Ecosyst. Environ. 74, 187-228. doi: 10.1016/S0167-8809(99)00037-7

Kunkel, B. A., Held, D. W., and Potter, D. A. (1999). Impact of halofenozide, imidacloprid, and bendiocarb on beneficial invertebrates and predatory activity in turfgrass. J. Econ. Entomol. 92, 922-930. doi: 10.1093/jee/92.4.922

Kunkel, B. A., Held, D. W., and Potter, D. A. (2001). Lethal and sublethal effects of bendiocarb, halofenozide, and imidacloprid on Harpalus pennsylvanicus (Coleoptera: Carabidae) following different modes of exposure in turfgrass. J. Econ. Entomol. 94, 60-67. doi: 10.1603/0022-0493-94.1.60

Lacey, L. A., Frutos, R., Kaya, H. K., and Vail, P. (2001). Insect pathogens as biological control agents: do they have a future? Biol. Control 21, 230-248. doi: 10.1006/bcon.2001.0938

Laffan, G. T., and Ashton, L. G. (1964). Dairy Farming in Australia. Sydney: Halstead Press.

Landis, D. A., Wratten, S. D., and Gurr, G. M. (2000). Habitat management to conserve natural enemies of arthropod pests in agriculture. Annu. Rev. Entomol. 45, 175-201. doi: 10.1146/annurev.ento.45.1.175

Lasley, P., Hogberg, M., Zane, H., and Larson, A. (2009). "People, grassland, and livestock in revitalized rural communities," in Young, C. A. Hume, D. E., and Mcculley, R. L. (2013). Forages and pastures symposium: fungal endophytes of tall fescue and perennial ryegrass: pasture friend or foe? J. Anim. Sci. 91, 2379-2394.

Lavelle, P., Decaëns, T., Aubert, M., Barot, S., Blouin, M., Bureau, F., et al. (2006). Soil invertebrates and ecosystem services. Eur. J. Soil Biol. 42(Suppl. 1), S3-S15. doi: 10.1016/j.ejsobi.2006.10.002

Leclerque, A., Hartelt, K., Schuster, C., Jung, K., and Kleespies, R. G. (2011). Multilocus sequence typing (MLST) for the infra-generic taxonomic classification of entomopathogenic Rickettsiella bacteria. FEMS Microbiol. Lett. 324, 125-134. doi: 10.1111/j.1574-6968.2011.02396.x

Leuchtmann, A., Bacon, C. W., Schardl, C. L., White, J. F. Jr., and Tadych, M. (2014). Nomenclatural realignment of Neotyphodium species with genus Epichloe. Mycologia 106, 202-215. doi: 10.3852/13-251

Lewis, E. E., Campbell, J., Griffin, C., Kaya, H., and Peters, A. (2006). Behavioral ecology of entomopathogenic nematodes. Biol. Control 38, 66-79. doi: $10.1016 /$ j.biocontrol.2005.11.007 
Lewis, E. E., Gaugler, R., and Harrison, R. (1993). Response of cruiser and ambusher entomopathogenic nematodes (Steinernematidae) to host volatile cues. Can. J. Zool. 71, 765-769. doi: 10.1139/z93-101

Lingg, A. J., and Donaldson, M. D. (1981). Biotic and abiotic factors affecting stability of Beauveria bassiana conidia in soil. J. Invertebr. Pathol. 38, 191-200. doi: 10.1016/0022-2011(81)90122-1

Loch, A. D., and Floyd, R. B. (2001). Insect pests of Tasmanian blue gum, Eucalyptus globulus globulus, in south-western Australia: history, current perspectives and future prospects. Aust. Ecol. 26, 458-466. doi: 10.1046/j.1442-9993.2001.01145.x

Longworth, J. F., and Archibald, R. D. (1975). A virus of black beetle, Heteronychus arator (F.) (Coleoptera: Scarabaeidae). N.Z. J. Zool. 2, 233-236. doi: 10.1080/03014223.1975.9517874

Longworth, J. F., and Carey, G. P. (1976). A small RNA virus with a divided genome from Heteronychus arator (F.) [Coleoptera: Scarabaeidae]. J. Gen. Virol. 33, 31-40. doi: 10.1099/0022-1317-33-1-31

Luff, M. L., and Rushton, S. P. (1989). The ground beetle and spider fauna of managed and unimproved upland pasture. Agric. Ecosyst. Environ. 25, 195-205. doi: 10.1016/0167-8809(89)90051-0

Lunt, I. D. (1991). Management of remnant lowland grasslands and grassy woodlands for nature conservation: a review. Vic. Nat. 108, 239-249.

Lunt, I. D., and Morgan, J. W. (2002). "The role of fire regimes in temperate lowland grasslands of south-eastern Australia," in Flammable Australia, eds R. A. Bradstock, J. E. Williams, and M. A. Gill (Cambridge: Cambridge University Press), 177-198.

Macleod, A., Wratten, S., Sotherton, N., and Thomas, M. (2004). "Beetle banks" as refuges for beneficial arthropods in farmland: long-term changes in predator communities and habitat. Agric. For. Entomol. 6, 147-154. doi: 10.1111/j.1461-9563.2004.00215.x

Malinowski, D. P., and Belesky, D. P. (2000). Adaptations of endophyteinfected cool-season grasses to environmental stresses: mechanisms of drought and mineral stress tolerance. Crop Sci. 40, 923-940. doi: $10.2135 /$ cropsci2000.404923x

Massey, F. P., Ennos, A. R., and Hartley, S. E. (2006). Silica in grasses as a defence against insect herbivores: contrasting effects on folivores and a phloem feeder. J. Anim. Ecol. 75, 595-603. doi: 10.1111/j.1365-2656.2006.01082.x

Massey, F. P., and Hartley, S. E. (2009). Physical defences wear you down: progressive and irreversible impacts of silica on insect herbivores. J. Anim. Ecol. 78, 281-291. doi: 10.1111/j.1365-2656.2008.01472.x

Massey, F. P., Roland Ennos, A., and Hartley, S. E. (2007). Herbivore specific induction of silica-based plant defences. Oecologia 152, 677-683. doi: 10.1007/s00442-007-0703-5

Matthiesse, J., and Learmonth, S. (1998). Seasonally contrasting activity of African black beetle, Heteronychus arator (Coleoptera: Scarabaeidae): implications for populations, pest status and management. Bull. Entomol. Res. 88, 443-450. doi: $10.1017 /$ S0007485300042188

Matthiessen, J. (1999). Late immature mortality is the major influence on reproductive success of African black beetle, Heteronychus arator (Fabricius) (Coleoptera: Scarabaeidae), in a Mediterranean-climate region of Australia. Aust. J. Entomol. 38, 348-353. doi: 10.1046/j.1440-6055.1999.00123.x

Matthiessen, J., and Learmonth, S. (1998). Seasonally contrasting activity of African black beetle, Heteronychus arator (Coleoptera: Scarabaeidae): implications for populations, pest status and management. Bull. Entomol. Res. 88, 443-450. doi: 10.1017/S0007485300042188

Matthiessen, J., and Ridsdill-Smith, T. (1991). Populations of African black beetle, Heteronychus arator (Coleoptera: Scarabaeidae) in a Mediterranean climate region of Australia. Bull. Entomol. Res. 81, 85-91. doi: 10.1017/S000748530005327X

Mcquillan, P. (1985). The identification of root-feeding cockchafer larvae (Coleoptera: Scarabaeidae) found in pastures in Tasmania. Aust. J. Zool. 33, 509-546. doi: 10.1071/ZO9850509

Mitchell, T. L. (1848). Journal of an Expedition Into the Interior of Tropical Australia. London: Longman, Brown, Green and Longmans.

Moate, P. J., Williams, S. R. O., Grainger, C., Hannah, M. C., Mapleson, D., Auldist, M. J., et al. (2012). Effects of wild-type, AR1 and AR37 endophyte-infected perennial ryegrass on dairy production in Victoria, Australia. Anim. Prod. Sci. 52, 1117-1130. doi: 10.1071/AN12126
Moon, C. D., Scott, D. B., Schardl, C. L., and Christensen, M. J. (2000). The evolutionary origins of Epichloë endophytes from annual ryegrasses. Mycologia 92, 1103-1118. doi: 10.2307/3761478

Nash, M. A., Thomson, L. J., and Hoffmann, A. A. (2008). Effect of remnant vegetation, pesticides, and farm management on abundance of the beneficial predator Notonomus gravis (Chaudoir) (Coleoptera: Carabidae). Biol. Control 46, 83-93. doi: 10.1016/j.biocontrol.2008.03.018

Oerke, E. C. (2006). Crop losses to pests. J. Agric. Sci. 144, 31-43. doi: $10.1017 /$ S0021859605005708

Oliver, I., Garden, D., Greenslade, P. J., Haller, B., Rodgers, D., Seeman, O., et al. (2005). Effects of fertiliser and grazing on the arthropod communities of a native grassland in south-eastern Australia. Agric. Ecosyst. Environ. 109, 323-334. doi: 10.1016/j.agee.2005.02.022

Oliver, J. W., Strickland, J. R., Waller, J. C., Fribourg, H. A., Linnabary, R. D., and Abney, L. K. (1998). Endophytic fungal toxin effect on adrenergic receptors in lateral saphenous veins (cranial branch) of cattle grazing tall fescue. J. Anim. Sci. 76, 2853-2856. doi: 10.2527/1998.76112853x

Ormerod, E. A., and Janson, O. E. (1889). Notes and Descriptions of a Few Injurious Farm \& Fruit Insects of South Africa. Compiled by Eleanor A. Ormerod...with Descriptions and Identifications of the Insects by Oliver E. Janson. London: Simpkin, Marshall \& Co.

Overbeck, G. E. (2014). The effects of grazing depend on productivity, and what else? J. Vegetation Sci. 25, 6-7. doi: 10.1111/jvs.12137

Paine, T. D., Steinbauer, M. J., and Lawson, S. A. (2011). Native and exotic pests of Eucalyptus: a worldwide perspective. Annu. Rev. Entomol. 56, 181-201. doi: 10.1146/annurev-ento-120709-144817

Panka, D., Piesik, D., Jeske, M., and Baturo-Ciesniewska, A. (2013). Production of phenolics and the emission of volatile organic compounds by perennial ryegrass (Lolium perenne L.)/Neotyphodium lolii association as a response to infection by Fusarium poae. J. Plant Physiol. 170, 1010-1019. doi: 10.1016/j.jplph.2013.02.009

Parbery, D. B. (1967). Pasture and Fodder Crop Plant Introductions at Kimberley Research Station, W.A. 1963-64: Part IV, Annual Grasses / by D. B. Parbery with 1965 Supplement Prepared in Collaboration with D. H. Mackenzie. Canberra, ACT: CSIRO, Division of Land Research.

Paterson, J., Forcherio, C., Larson, B., Samford, M., and Kerley, M. (1995). The effects of fescue toxicosis on beef cattle productivity. J. Anim. Sci. 73, 889-898. doi: $10.2527 / 1995.733889 x$

Pearson, M., and Lennon, J. (2010). Pastoral Australia: Fortunes, Failures \& Hard Yakka: A Historical Overview 1788-1967. Collingwood, VIC: CSIRO Publishing.

Pennell, C. G. L., Popay, A. J., Ball, O. J. P., Hume, D. E., and Baird, D. B. (2005). Occurrence and impact of pasture mealybug (Balanococcus poae) and root aphid (Aploneura lentisci) on ryegrass (Lolium spp.) with and without infection by Neotyphodium fungal endophytes. N.Z. J. Agric. Res. 48, 329-337. doi: 10.1080/00288233.2005.9513663

Pettersson, B., Rippere, K. E., Yousten, A. A., and Priest, F. G. (1999). Transfer of Bacillus lentimorbus and Bacillus popilliae to the genus paenibacillus with emended descriptions of Paenibacillus lentimorbus comb. nov. and Paenibacillus popilliae comb. nov. Int. J. Syst. Bacteriol. 49, 531-540. doi: 10.1099/00207713-49-2-531

Pietersen, D. W., and Symes, C. T. (2010). Assessing the diet of amur falcon falco amurensis and lesser kestrel falco naumanni using stomach content analysis. Ostrich 81, 39-44. doi: 10.2989/00306525.2010.455817

Pinkard, E. A., Baillie, C. C., Patel, V., Paterson, S., Battaglia, M., Smethurst, P. J., et al. (2006b). Growth responses of Eucalyptus globulus Labill. to nitrogen application and severity, pattern and frequency of artificial defoliation. For. Ecol. Manag. 229, 378-387. doi: 10.1016/j.foreco.2006. 04.016

Pinkard, E. A., Baillie, C., Patel, V., and Mohammed, C. L. (2006a). Effects of fertilising with nitrogen and phosphorus on growth and crown condition of Eucalyptus globulus Labill. experiencing insect defoliation. For. Ecol. Manag. 231, 131-137. doi: 10.1016/j.foreco.2006.05.026

Pinkard, E. A., Battaglia, M., and Mohammed, C. L. (2007). Defoliation and nitrogen effects on photosynthesis and growth of Eucalyptus globulus. Tree Physiol. 27, 1053-1063. doi: 10.1093/treephys/27.7.1053

Plant Health Australia (2001). Australian Plant Pest Database, Online database (accessed 2014). Plant Health Australia. 
Popay, A. J., and Thom, E. R. (2009). Endophyte effects on major insect pests in Waikato dairy pasture. Proc. N.Z. Grassland Assoc. 71, 121-126.

Potter, D. A., Patterson, C. G., and Redmond, C. T. (1992). Influence of turfgrass species and tall fescue endophyte on feeding ecology of Japanese beetle and southern masked chafer grubs (Coleoptera: Scarabaeidae). J. Econ. Entomol. 85, 900-909. doi: 10.1093/jee/85.3.900

Prabhaker, N., Castle, S. J., Naranjo, S. E., Toscano, N. C., and Morse, J. G. (2011). Compatibility of two systemic neonicotinoids, imidacloprid and thiamethoxam, with various natural enemies of agricultural pests. J. Econ. Entomol. 104, 773-781. doi: 10.1603/EC10362

Prestidge, R. A., and Gallagher, R. T. (1988a). "Acremonium endophyte in perennial ryegrass, ryegrass staggers in lambs, and growth rate of Argentine stem weevil larvae," in Proceedings of the 5th Australasian Conference on Grassland Invertebrate Ecology, Melbourne, Australia, ed P. P. Stahle (Melbourne, VIC: D\&D Printing), 229-235.

Prestidge, R. A., and Gallagher, R. T. (1988b). Endophyte fungus confers resistance to ryegrass: argentine stem weevil larval studies. Ecol. Entomol. 13, 429-435. doi: 10.1111/j.1365-2311.1988.tb00375.x

Prestidge, R. A., Pottinger, R. P., and Barker, G. M. (1982). "An association of Lolium endophyte with ryegrass resistance to Argentine stem weevil," in Proceedings of the 35th New Zealand Weed and Pest Control Conference (Waikato), 119-122.

Reed, K. F. M., and Cocks, P. S. (1982). "Some limitations of pasture species in southern Australia," in Proceedings of the Second Australian Agronomy Conference, (Wagga Wagga, NSW), 142-160.

Reed, K. F. M., Mace, W. J., Walker, L. V., and Fletcher, L. R. (2016). Endophyte metabolites associated with perennial ryegrass toxicosis. Anim. Prod. Sci. 56, 895-907. doi: 10.1071/AN14495

Reynolds, O. L., Keeping, M. G., and Meyer, J. H. (2009). Silicon-augmented resistance of plants to herbivorous insects: a review. Ann. Appl. Biol. 155, 171-186. doi: 10.1111/j.1744-7348.2009.00348.x

Riechert, S. E. (1999). The hows and whys of successful pest suppression by spiders: insights from case studies. J. Arachnol. 27, 387-396.

Rippere, K. E., Tran, M. T., Yousten, A. A., Hilu, K. H., and Klein, M. G. (1998). Bacillus popilliae and Bacillus lentimorbus, bacteria causing milky disease in Japanese beetles and related scarab larvae. Int. J. Syst. Bacteriol. 48, 395-402. doi: 10.1099/00207713-48-2-395

Rolls, E. C. (1999). Land of grass: the loss of Australia's Grasslands. Aust. Geogr. Stud. 37, 197-213. doi: 10.1111/1467-8470.00079

Romeis, J., Meissle, M., and Bigler, F. (2006). Transgenic crops expressing Bacillus thuringiensis toxins and biological control. Nat. Biotechnol. 24, 63-71. doi: $10.1038 / \mathrm{nbt} 1180$

Root, R. B. (1973). Organization of a plant-arthropod association in simple and diverse habitats: the fauna of collards (Brassica Oleracea). Ecol. Monogr. 43, 95-124. doi: 10.2307/1942161

Rowan, D. D. (1993). Lolitrems, peramine and paxilline: mycotoxins of the ryegrass/endophyte interaction. Agric. Ecosyst. Environ. 44, 103-122. doi: 10.1016/0167-8809(93)90041-M

Rowan, D. D., and Gaynor, D. L. (1986). Isolation of feeding deterrents against argentine stem weevil from ryegrass infected with the endophyte Acremonium loliae. J. Chem. Ecol. 12, 647-658. doi: 10.1007/BF01012099

Rushton, S. P., Luff, M. L., and Eyre, M. D. (1989). Effects of pasture improvement and management on the ground beetle and spider communities of upland grasslands. J. Appl. Ecol. 26, 489-503. doi: 10.2307/2404076

Saikkonen, K., Ruokolainen, K., Huitu, O., Gundel, P. E., Piltti, T., Hamilton, C. E., et al. (2013). Fungal endophytes help prevent weed invasions. Agric. Ecosyst. Environ. 165, 1-5. doi: 10.1016/j.agee.2012.12.002

Sampson, K. (1933). The systemic infection of grasses by Epichloe typhina (Pers.) Tul. Trans. Br. Mycol. Soc. 18, 30-IN3. doi: 10.1016/s0007-1536(33)8 0025-8

Sanchis, V. (2010). Bacillus thuringiensis. Available online at: http://www.komunich.de/vincent-sanchis/france/bacillus-thuringiensis.html (Accessed September 23, 2015)

Sanson, G., Read, J., Aranwela, N., Clissold, F., and Peeters, P. (2001). Measurement of leaf biomechanical properties in studies of herbivory: opportunities, problems and procedures. Aust. Ecol. 26, 535-546. doi: 10.1046/j.1442-9993.2001.01154.x
Schardl, C. L. (1996). EPICHLOË SPECIES: fungal symbionts of grasses. Annu. Rev. Phytopathol. 34, 109-130. doi: 10.1146/annurev.phyto.34.1.109

Schardl, C. L., Grossman, R. B., Nagabhyru, P., Faulkner, J. R., and Mallik, U. P. (2007). Loline alkaloids: currencies of mutualism. Phytochemistry 68, 980-996. doi: 10.1016/j.phytochem.2007.01.010

Schofield, C. R. (1990). Bombala: Hub of Southern Monaro. Bombala: Bombala Shire Council.

Schünemann, R., Knaak, N., and Fiuza, L. M. (2014). Mode of action and specificity of Bacillus thuringiensis toxins in the control of caterpillars and stink bugs in soybean culture. ISRN Microbiol. 2014, 12. doi: 10.1155/2014/135675

Scott, B. J., Ridley, A. M., and Conyers, M. K. (2000). Management of soil acidity in long-term pastures of south-eastern Australia: a review. Aust. J. Exp. Agric. 40, 1173-1198. doi: 10.1071/EA00014

Shapiro-Ilan, D. I., Han, R., and Dolinksi, C. (2012). Entomopathogenic nematode production and application technology. J. Nematol. 44, 206-217.

Siegel, M. R., Latch, G. C. M., and Johnson, M. C. (1987). Fungal endophytes of grasses. Annu. Rev. Phytopathol. 25, 293-315. doi: 10.1146/annurev.py.25.090187.001453

Sivasupramaniam, S., Moar, W. J., Ruschke, L. G., Osborn, J. A., Jiang, C., Sebaugh, J. L., et al. (2008). Toxicity and characterization of cotton expressing Bacillus thuringiensis Cry1Ac and Cry2Ab2 proteins for control of lepidopteran pests. J. Econ. Entomol. 101, 546-554. doi: 10.1093/jee/ 101.2.546

Smith, B. L., Mcleay, L. M., and Embling, P. P. (1997). Effect of the mycotoxins penitrem, paxilline and lolitrem B on the electromyographic activity of skeletal and gastrointestinal smooth muscle of sheep. Res. Vet. Sci. 62, 111-116. doi: 10.1016/S0034-5288(97)90130-2

Stahly, D., Andrews, R., and Yousten, A. (2006). "The fenus bacillus-insect pathogens," in The Prokaryotes, eds M. Dworkin, S. Falkow, E. Rosenberg, K.-H. Schleifer, and E. Stackebrandt (Springer US), 536-608.

Stahly, D. P., and Klein, M. G. (1992). Problems with in vitro production of spores of Bacillus popilliae for use in biological control of the Japanese beetle. J. Invertebr. Pathol. 60, 283-291. doi: 10.1016/0022-2011(92)90010-2

Steinbauer, M. J. (2001). Specific leaf weight as an indicator of juvenile leaf toughness in Tasmanian bluegum (Eucalyptus globulus ssp. globulus): implications for insect defoliation. Austr. For. 64, 32-37. doi: 10.1080/00049158.2001.10676158

Steinkraus, K. H., and Tashiro, H. (1967). Milky disease bacteria. Appl. Microbiol. $15,325-333$

Stone, D. I., and Garden, D. S. (1978). Squatters and Settlers. Terry Hills: Reed.

Stott, K. J., and Gourley, C. J. P. (2016). Intensification, nitrogen use and recovery in grazing-based dairy systems. Agric. Syst. 144, 101-112. doi: 10.1016/j.agsy.2016.01.003

Strickland, J. R., Cross, D. L., Birrenkott, G. P., and Grimes, L. W. (1994). Effect of ergovaline, loline, and dopamine antagonists on rat pituitary cell prolactin release in vitro. Am. J. Vet. Res. 55, 716-721.

Tallowin, J. R. B., Rook, A. J., and Rutter, S. M. (2005). Impact of grazing management on biodiversity of grasslands. Anim. Sci. 81, 193-198. doi: 10.1079/ASC50780193

Taylor, F. (1951). The black maize beetle (Heteronychus sanctaehelenae). Farming S. Afr. 26, 299-302.

Taylor, P. (1982). Australia, the First Twelve Years. Sydney: Allen \& Unwin.

Thom, E. R., Popay, A. J., Waugh, C. D., and Minneé, E. M. (2014). Impact of novel endophytes in perennial ryegrass on herbage production and insect pests from pastures under dairy cow grazing in northern New Zealand. Grass Forage Sci. 69, 191-204. doi: 10.1111/gfs.12040

Thom, E. R., Waugh, C. D., Minneé, E. M. K., and Waghorn, G. C. (2013). Effects of novel and wild-type endophytes in perennial ryegrass on cow health and production. N.Z. Vet. J. 61, 87-97. doi: 10.1080/00480169.2012.715379

Tilman, D., Cassman, K. G., Matson, P. A., Naylor, R., and Polasky, S. (2002). Agricultural sustainability and intensive production practices. Nature 418, 671-677. doi: 10.1038/nature01014

Todd, D. H. (1959). Black beetle heteronychus sanctae helenae blanch., in pastures in New Zealand. N.Z. J. Agric. Res. 2, 1262-1273.

Tscharntke, T., Klein, A. M., Kruess, A., Steffan-Dewenter, I., and Thies, C. (2005). Landscape perspectives on agricultural intensification and biodiversity-ecosystem service management. Ecol. Lett. 8, 857-874. doi: $10.1111 / \mathrm{j} .1461-0248.2005 .00782 . \mathrm{x}$ 
Tsitsilas, A., Stuckey, S., Hoffmann, A., Weeks, A., and Thomson, L. (2006). Shelterbelts in agricultural landscapes suppress invertebrate pests. Anim. Prod. Sci. 46, 1379-1388. doi: 10.1071/EA05137

Valentine, E. W. (1979). "The parasites and predators of Heteronychus arator in South Africa Coleoptera: Scarabaeidae," in Proceedings of the 2nd Australasian Conference on Grassland Invertebrate Ecology (Palmerston North), 216-219.

Van Frankenhuyzen, K. (2009). Insecticidal activity of Bacillus thuringiensis crystal proteins. J. Invertebr. Pathol. 101, 1-16. doi: 10.1016/j.jip.2009.02.009

Walston, A. T., Held, D. W., Mason, N. R., and Potter, D. A. (2001). Absence of interaction between endophytic perennial ryegrass and susceptibility of Japanese beetle (Coleoptera:Scarabaeidae) grubs to Paenibacillus popilliae dutky. J. Entomol. Sci. 36, 105-108.

Watson, B., (2006). "The effect of endophyte in perennial ryegrass and tall fescue on red and blackheaded pasture cockchafers," in Proceedings of the 6th International Symposium on Fungal Endophytes on Grasses, eds A. J. Popay and E. R. Thom (Christchurch).

Watson, R. N. (1979). "Dispersal and distribution of Heteronychus arator in New Zealand (Coleoptera: Scarabaeidae)," in Proceedings of the 2nd Australasian Conference on Grassland Invertebrate Ecology (Palmerston North), 149-152.

Wilkins, P. W. (1991). Breeding perennial ryegrass for agriculture. Euphytica 52, 201-214. doi: 10.1007/BF00029397

Wilson, D. (1993). Fungal endophytes: out of sight but should not be out of mind. Oikos 68, 379-384. doi: 10.2307/3544856

Woltz, J. M., Isaacs, R., and Landis, D. A. (2012). Landscape structure and habitat management differentially influence insect natural enemies in an agricultural landscape. Agric. Ecosyst. Environ. 152, 40-49. doi: 10.1016/j.agee.2012.02.008

Wright, W. E. (1958). The black beetle (Heteronychus sanctae-helenae Blanch.). Agric. Gazette N.S.W. 69, 422-427.
Yang, B., Thorogood, D., Armstead, I., and Barth, S. (2008). How far are we from unravelling self-incompatibility in grasses? New Phytol. 178, 740-753. doi: 10.1111/j.1469-8137.2008.02421.x

Young, C. A., Hume, D. E., and McCulley, R. L. (2013). Forages and pastures symposium: fungal endophytes of tall fescue and perennial ryegrass: pasture friend or foe? J. Anim. Sci. 91, 2379-2394. doi: 10.2527/jas. 2012-5951

Younger, R. (1993). The Romance of the Stockman: The Lore, Legend and Literature of Australia's Outback Heroes. Ringwood, VIC: Viking O’Neil.

Zain, M. E. (2011). Impact of mycotoxins on humans and animals. J. Saudi Chem. Soc. 15, 129-144. doi: 10.1016/j.jscs.2010.06.006

Zhang, J., Hodgman, T. C., Krieger, L., Schnetter, W., and Schairer, H. U. (1997). Cloning and analysis of the first cry gene from Bacillus popilliae. J. Bacteriol. 179, 4336-4341. doi: 10.1128/jb.179.13.4336-4341.1997

Zimmermann, G. (2007). Review on safety of the entomopathogenic fungi Beauveria bassiana and Beauveria brongniartii. Biocontrol Sci. Technol. 17, 553-596. doi: 10.1080/09583150701309006

Conflict of Interest Statement: The authors declare that the research was conducted in the absence of any commercial or financial relationships that could be construed as a potential conflict of interest.

Copyright (c) 2017 Karpyn Esqueda, Yen, Rochfort, Guthridge, Powell, Edwards and Spangenberg. This is an open-access article distributed under the terms of the Creative Commons Attribution License (CC BY). The use, distribution or reproduction in other forums is permitted, provided the original author (s) or licensor are credited and that the original publication in this journal is cited, in accordance with accepted academic practice. No use, distribution or reproduction is permitted which does not comply with these terms. 